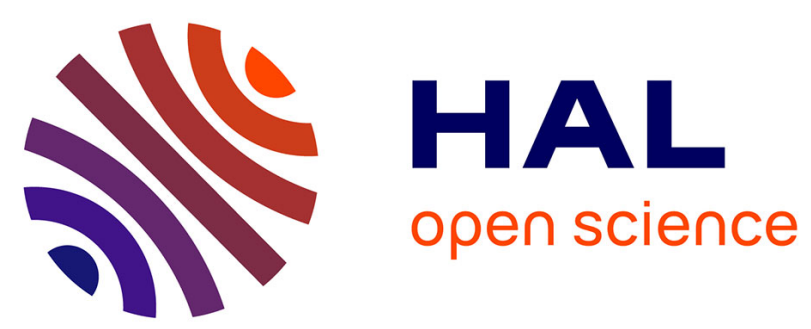

\title{
Effect of Corrosion on the High Cycle Fatigue Strength of Martensitic Stainless Steel X12CrNiMoV12-3
}

Mohamed El May, Thierry Palin-Luc, Nicolas Saintier, Olivier Devos

\section{To cite this version:}

Mohamed El May, Thierry Palin-Luc, Nicolas Saintier, Olivier Devos. Effect of Corrosion on the High Cycle Fatigue Strength of Martensitic Stainless Steel X12CrNiMoV12-3. International Journal of Fatigue, 2012, pp.10.1016/j.ijfatigue.2012.09.018. 10.1016/j.ijfatigue.2012.09.018 . hal-00748668

\section{HAL Id: hal-00748668 https://hal.science/hal-00748668}

Submitted on 6 Nov 2012

HAL is a multi-disciplinary open access archive for the deposit and dissemination of scientific research documents, whether they are published or not. The documents may come from teaching and research institutions in France or abroad, or from public or private research centers.
L'archive ouverte pluridisciplinaire HAL, est destinée au dépôt et à la diffusion de documents scientifiques de niveau recherche, publiés ou non, émanant des établissements d'enseignement et de recherche français ou étrangers, des laboratoires publics ou privés. 


\section{Accepted Manuscript}

Effect of Corrosion on the High Cycle Fatigue Strength of Martensitic Stainless Steel X12CrNiMoV12-3

Mohamed El May, Thierry Palin-Luc, Nicolas Saintier, Olivier Devos

PII:

S0142-1123(12)00282-4

DOI:

http://dx.doi.org/10.1016/j.ijfatigue.2012.09.018

Reference:

JIJF 2979

To appear in:

International Journal of Fatigue

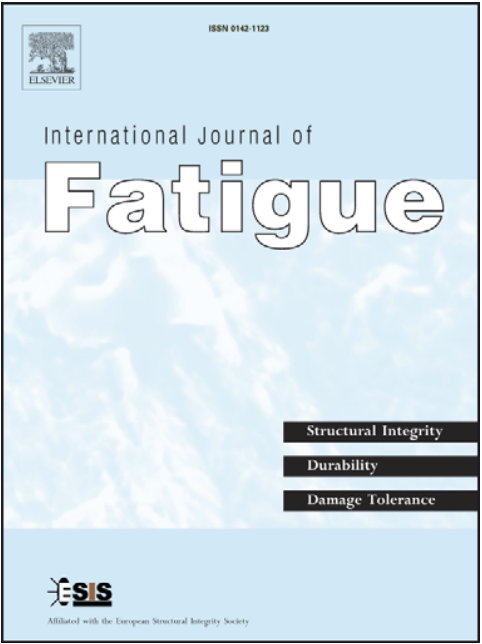

Received Date: $\quad 17$ April 2012

Revised Date: $\quad 13$ September 2012

Accepted Date: $\quad 25$ September 2012

Please cite this article as: May, M.E., Palin-Luc, T., Saintier, N., Devos, O., Effect of Corrosion on the High Cycle Fatigue Strength of Martensitic Stainless Steel X12CrNiMoV12-3, International Journal of Fatigue (2012), doi: http://dx.doi.org/10.1016/j.ijfatigue.2012.09.018

This is a PDF file of an unedited manuscript that has been accepted for publication. As a service to our customers we are providing this early version of the manuscript. The manuscript will undergo copyediting, typesetting, and review of the resulting proof before it is published in its final form. Please note that during the production process errors may be discovered which could affect the content, and all legal disclaimers that apply to the journal pertain. 
EFFECT OF CORROSION ON THE HIGH CYCLE FATIGUE STRENGTH OF MARTENSITIC STAINLESS STEEL X12CrNiMoV12-3

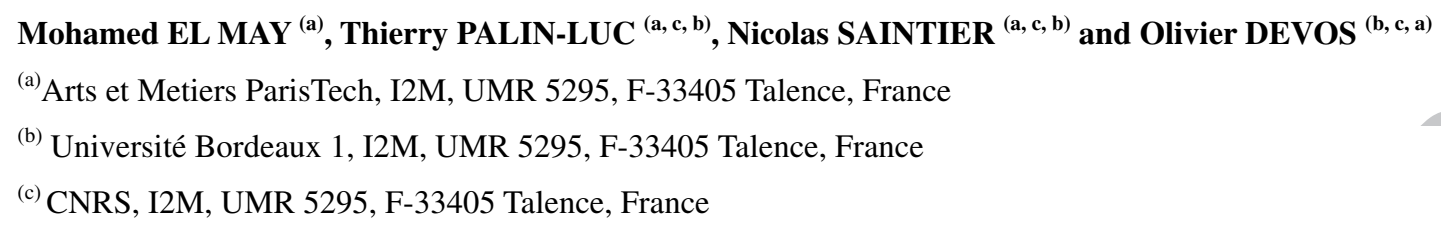

\section{Abstract}

This paper addresses the effects of corrosion on the high cycle fatigue (HCF) strength of a high mechanical strength martensitic stainless steel (X12CrNiMoV12-3) that is used in aeronautic applications. HCF tests (between $10^{5}$ and $10^{7}$ cycles) were carried out in two environments: (i) in air and (ii) in an aqueous solution $(\mathrm{pH}=6)$ of $0.1 \mathrm{M} \mathrm{NaCl}+0.044 \mathrm{M}$ $\mathrm{Na}_{2} \mathrm{SO}_{4}$ at a loading frequency of $120 \mathrm{~Hz}$. Surface crack initiation is observed in air, whereas in solution, the crack initiated at corrosion defects. The decrease observed in the corrosion fatigue strength of specimens at $10^{7}$ cycles was $33 \%$ of that of similar specimens tested in air. The electrochemical behaviour of the passive film was investigated during fatigue testing in a $\mathrm{NaCl}$ aqueous solution by monitoring the free potential and through electrochemical impedance spectroscopy (EIS). Based on fractography analysis and the EIS tests results, fatigue crack initiation mechanisms in air and in the $\mathrm{NaCl}$ aqueous solution were identified. A scenario for fatigue crack initiation is proposed based on the physical evidence. Local passive film ruptures are the cause of the corrosion fatigue crack initiation. The film is broken by material strain from the applied cyclic stress during fatigue testing, causing increased local corrosive attack. This effect has been shown at $10 \mathrm{~Hz}$ and $120 \mathrm{~Hz}$ because the characteristic time for repassivation for the steel is very low compared to the period of the cyclic loading.

Keywords: corrosion fatigue; stainless steel; sodium chloride aqueous solution; high cycle fatigue; electrochemical impedance spectroscopy; passive film. 


\section{Nomenclature}

$\begin{array}{ll}\text { A: } & \text { Fracture elongation (in \%) } \\ \sigma_{\mathrm{u}}: & \text { Ultimate tensile strength under quasi-static monotonic tension } \\ \sigma_{0.2}: & \text { Conventional yield strength with } 0.2 \% \text { plastic deformation } \\ \mathrm{E}: & \text { Young modulus } \\ \sigma_{\mathrm{a}}: & \text { Stress amplitude } \\ \sigma_{\mathrm{R}=-1}^{\mathrm{D}}: & \text { Median fatigue strength (in amplitude) at } 10^{7} \text { cycles under } \mathrm{R}=-1 \\ \sigma_{\mathrm{R}=0.1}^{\mathrm{D}}: & \text { Median fatigue strength (in amplitude) at } 10^{7} \text { cycles under } \mathrm{R}=0.1 \\ \mathrm{R}: & \text { Loading ratio } \\ \mathrm{f}: & \text { Loading frequency } \\ \mathrm{N}_{\mathrm{f}}: & \text { Number of cycles to failure } \\ \mathrm{K}_{\mathrm{t}}: & \text { Theoretical stress concentration factor } \\ \mathrm{R}_{\mathrm{a}}: & \text { Arithmetic surface roughness }\end{array}$

\section{Introduction}

Currently, engineering departments are aware that corrosion and fatigue must be taken into account when designing aircraft structures. Indeed, most aircraft structures experience both cyclic loading and aggressive chemical environments (especially in confined component regions) during their service lives. Aeronautic materials with high specific strength are being developed to fulfil the newest requirements in aircraft design. However, their usefulness depends on their corrosion fatigue strength. In this study, the effects of aqueous corrosion on the high cycle fatigue (HCF) strength (between $10^{5}$ and $10^{7}$ cycles) of the martensitic stainless steel X12CrNiMoV12-3 are investigated.

The combined influence of corrosion and cyclic loading is known to affect the mechanical properties of metallic alloys and has been shown to initiate cracks from corrosion-induced surface defects. Corrosion fatigue in $\mathrm{NaCl}$ aqueous solutions has been studied by numerous researchers [1-8]. A number of crack initiation mechanisms have been suggested, including competition between pit growth and short crack growth [1], preferential dissolution of plastically deformed material [2], local rupture of the passive film by persistent slip bands (PSB) [3] and hydrogen embrittlement in the cathodic domain and deformation/corrosion synergy effects [4]. However, all these mechanisms depend on the experimental conditions 
(loading frequency, stress-strain level, environment, electrochemical potential value, etc.) and on material properties (e.g., cleanness, segregation, etc.).

Corrosion fatigue failure has been mainly investigated on austenitic or ferritic stainless steels in the LCF regime (i.e., with significant macroscopic plastic strain amplitude), under severe environments and with low loading frequencies (typically ranging from 0.1 to a few $\mathrm{Hz}$, with a maximum of $60 \mathrm{~Hz}$ ). A few works by Palin-luc et al. [5] or Ebara [6], for instance, were carried out at very high frequencies $(20 \mathrm{kHz})$ for studying the effects of corrosion under very small strain amplitudes leading into the very high cycle fatigue (VHCF) regime $\left(10^{9}\right.$ cycles and greater). However, the literature shows that the effect of loading frequency on corrosion fatigue crack initiation life depends on the interaction between the metal and the environment. Therefore, many studies have been devoted to evaluating the effects of the loading frequency in the range of $0.1 \mathrm{~Hz}$ to $60 \mathrm{~Hz}[1,7]$. Some of these works noted that corrosion produces greater damage at low frequencies than at high frequencies because the duration of exposure in corrosive environments at high stress levels is longer. It is usually considered that above some frequency threshold, the damage may be due only to cyclic stress and/or strain; If the loading frequency is high enough the characteristic time of the corrosion process is too long compared to the loading period. However, this is not always true. For instance, Palin-luc et al. [5] used hot rolled low-alloy grade R5 steel to demonstrate the important effect of corrosive environment (in a $3 \% \mathrm{NaCl}$ aqueous solution referred to as $\mathrm{A} 3$ synthetic sea water, see the ASTM G85 standard) on fatigue strength in the gigacycle regime during tests at very high frequency $(20 \mathrm{kHz})$. The fatigue strength at $4 \times 10^{8}$ cycles under A3 sea water flow is divided by four. This example shows that the frequency effect in corrosion fatigue is not well understood.

The purpose of this paper is to understand the initiation mechanism for corrosion fatigue cracking on a martensitic stainless steel loaded in the HCF domain ( $10^{5}$ to $10^{7}$ cycles). The corrosive environment is a $\mathrm{NaCl}$ aqueous solution. To investigate the corrosion fatigue phenomenon, in-situ electrochemical impedance spectroscopy (EIS) tests were carried out during the corrosion fatigue tests. These experiments and SEM observations of the fracture surface of the specimens allow us to understand the corrosion fatigue damage phenomena and to propose a fatigue crack initiation scenario based on the physical evidence. Furthermore, the effect of the loading frequency was investigated using two different values $(10 \mathrm{~Hz}$ and 120 $\mathrm{Hz}$ ), leading to a realistic fatigue test duration of $10^{7}$ cycles. 


\section{Material and experimental procedure}

\section{Material}

The material being investigated is a high strength rolled martensitic stainless steel (X12CrNiMoV12-3) developed for aeronautic applications. Its chemical composition and mechanical properties under quasi-static monotonic tension are shown in Tables 1 and 2. The microstructure of this steel is completely martensitic, as shown in Figure 1 (residual austenite content is less than 1\%). Austenitic grains have an equiaxed structure and the grain size is approximately $100 \mu \mathrm{m}$ (class 5, according to the ASTM standard).

\section{Specimens and corrosive environment}

Fatigue tests were carried out in air and in a corrosive $0.1 \mathrm{M} \mathrm{NaCl}+0.044 \mathrm{M} \mathrm{Na}_{2} \mathrm{SO}_{4}$ aqueous solution. The fatigue tests in air were performed using $8 \mathrm{~mm}$ diameter cylindrical specimens with a theoretical stress concentration factor in tension of $\mathrm{K}_{\mathrm{t}}=1.04$ (Figure 2.a). The corrosion fatigue tests in aqueous solution were also carried out using $8 \mathrm{~mm}$ diameter cylindrical specimens $\left(\mathrm{K}_{\mathrm{t}}=1.04\right)$ (Figure 2.b). The arithmetic roughness of the area of interest was less than or equal to $R_{a}=0.1 \mu \mathrm{m}$ for all the specimens.

\section{Fatigue tests conditions and electrochemical measurement technique}

Fatigue tests were carried out under axial loading and load controlled under free potential. Except for investigating the frequency effect, all the fatigue tests were performed at $120 \mathrm{~Hz}$ with a resonant electromagnetic fatigue testing machine (Vibrophore type) (Figure 3.a). This frequency was chosen so that failure between $10^{5}$ and $10^{7}$ cycles could be reached in a reasonable time. Moreover, this loading frequency is typical for an HCF test, even if it is higher than what is usually used for corrosion fatigue studies. The stop criterion was a loading frequency drop of $0.7 \mathrm{~Hz}$, corresponding to a technical fatigue crack with a typical surface length of $5 \mathrm{~mm}$ and a depth of $2 \mathrm{~mm}$. For testing at $10 \mathrm{~Hz}$ and investigating the effect of the loading frequency, a servo-hydraulic fatigue testing machine was used.

An electrochemical corrosion cell was developed and produced at the laboratory (compatible with both the vibrophore and the servo-hydraulic testing machine). This cell allows in-situ fatigue testing in an aqueous corrosive environment. The specimens were electrically isolated from the frame of the fatigue testing machine. The whole gauge section (area of interest) of the specimen was electrochemically monitored using a potentiostat device (Versastat4). A three electrode cell was used for the electrochemical investigation with a saturated calomel electrode (SCE) as the reference maintained at a constant distance $(3 \mathrm{~mm})$ from the specimen 
surface, a platinum counter electrode (CE) and the specimen as the working electrode (WE) (Figure 3.b). The electrochemical investigation was carried out at both steady state and transient regimes. Two electrochemical techniques were used in this study: voltammetry and electrochemical impedance spectroscopy (EIS). The latter, which is a dynamic technique, is well known for its ability to analyse the electrochemical mechanism occurring at the interface between the electrode and the solution [8]. A Versastat4 device was used in galvanostat mode to impose a stationary zero current at the working electrode (the specimen) corresponding to the free potential. Then, a frequency response analyser imposes a small amplitude sine wave current modulation $( \pm 6 \mu \mathrm{A})$ scanning through frequencies from $100 \mathrm{~Hz}$ up to $0.1 \mathrm{~Hz}$. The high frequency range provides information on the passive film and/or on the kinetics of the corrosion process, whereas the low frequency domain characterises slow processes, such as the diffusion of ionic species in the solution to and from the electrode surface. During the corrosion fatigue tests, the impedance measurements were performed at the free potential every 30 min to investigate the electrochemical behaviour as a function of time.

Finally, the fracture surfaces of all the specimens were observed with optical and scanning electron microscopy (SEM) to investigate the crack initiation mechanisms.

\section{Results and discussion}

\section{$S$ - $N$ curves in air and in $\mathrm{NaCl}$ aqueous solution}

The S-N curves of the X12CrNiMoV12-3 stainless steel under fully reversed tension in air and in the aqueous solution are shown in Figure 4 for two loading ratios, $R=-1$ and $R=0.1$. These curves are normalised by the ultimate tensile strength $\left(\sigma_{\mathrm{u}}\right)$. The results show a significant decrease in the fatigue strength for the specimens in the corrosive aqueous $0.1 \mathrm{M}$ $\mathrm{NaCl}$ solution compared to those in air. The median fatigue strength at $10^{7}$ cycles of the specimens in the aqueous solution decreases by $33 \%$ compared to those tested in air. Some corrosion fatigue tests in the aqueous solution without $\mathrm{NaCl}$ were performed to understand the role of the chloride ions. Similar to the corrosion fatigue test in the $(0.1 \mathrm{M} \mathrm{NaCl}+0.044 \mathrm{M}$ $\mathrm{Na}_{2} \mathrm{SO}_{4}$ ) aqueous solution, the results show a significant decrease in the corrosion fatigue strength in the $0.1 \mathrm{M} \mathrm{Na}_{2} \mathrm{SO}_{4}$ aqueous solution and in distilled water compared to air (Figure 4.b). The SEM observations show that the fatigue cracks initiated at surface corrosion defects (indicated by arrows on Figures 5.c to 5.f) in all the aqueous testing solutions $(0.1 \mathrm{M} \mathrm{NaCl}+$ $0.044 \mathrm{M} \mathrm{Na}_{2} \mathrm{SO}_{4}, 0.1 \mathrm{M} \mathrm{Na}_{2} \mathrm{SO}_{4}$ and distilled water). For the fatigue test in air, fatigue crack initiation sites are located on the specimen surface (indicated by arrows on Figures 5.a and 
5.b). No clear evidence of defects (pores, inclusions, etc) was found at the crack initiation locations.

We conclude that the corrosive effect (depassivation of the material) is not dependent solely on the chloride content in the environment because for the $0.1 \mathrm{M} \mathrm{Na}_{2} \mathrm{SO}_{4}$ solution and the distilled water, the decreasing of the fatigue strength is also important. In the remainder of this paper, we explain this phenomenon in detail through the combined role of PSBs and the aqueous environment on the depassivation phase of the studied material.

\section{Effect of cyclic loading on the free potential of the metal}

To understand the electrochemical reactivity of the surface during cyclic loading, linear scan voltammetry was performed without any mechanical loading (no cyclic and no static stress), in solution $\left(0.1 \mathrm{M} \mathrm{NaCl}+0.044 \mathrm{M} \mathrm{Na} \mathrm{SO}_{4}\right)$. Note that the free potential of the $\mathrm{X} 12 \mathrm{CrNiMoV} 12-3$ steel without any mechanical load is approximately $+0.1 \mathrm{~V} / \mathrm{SCE}$, which is greater than that measured by Turnbull et al. using a similar material [9]. The free potential in the presence of chloride and sulphate ions was close to $-0.2 \mathrm{~V} / \mathrm{SCE}$. The difference between the two potentials was most likely due to the surface finish $(\mathrm{Ra}<0.1 \mu \mathrm{m})$.

The potential was applied from $-1 \mathrm{~V} / \mathrm{SCE}$ up to $+0.6 \mathrm{~V} / \mathrm{SCE}$ at a scanning rate of $0.01 \mathrm{~V} / \mathrm{s}$ (Figure 6). The cathodic potential corresponding to the water reduction was chosen to reduce the passive oxide layer. Thus, an activation corrosion peak was observed around $-0.4 \mathrm{~V} / \mathrm{SCE}$ due to the iron oxidation involved as a result of the passive layer dissolution. A well defined corrosion potential $\mathrm{E}_{\mathrm{corr}}$ was measured at $-0.44 \mathrm{~V} / \mathrm{SCE}$. When the potential was shifted to be more anodic, the current decreased until becoming slightly positive. This potential range corresponds to the passivation domain, extending from -0.25 to $+0.3 \mathrm{~V} / \mathrm{SCE}$.

The free potential was recorded during cyclic loading (corrosion fatigue tests) in the same environment $\left(0.1 \mathrm{M} \mathrm{NaCl}+0.044 \mathrm{M} \mathrm{Na}_{2} \mathrm{SO}_{4}\right.$ aqueous solution). Under cyclic loading, the free potential decreased to approximately $-0.4 \mathrm{~V} / \mathrm{SCE}$ (Figure 7). As shown in Figure 6, this value corresponds to the activated corrosion peak observed in the linear scan voltammetry, showing a rupture of the passive film. For the corrosion fatigue test in the $0.1 \mathrm{M} \mathrm{Na}_{2} \mathrm{SO}_{4}$ aqueous solution without chlorides, the free potential also decreased to around $-0.4 \mathrm{~V} / \mathrm{SCE}$ under cyclic loading. Note that the concentration of $\mathrm{Na}_{2} \mathrm{SO}_{4}(0.1 \mathrm{M})$ was chosen to have the same ionic strength as in the $\left(0.1 \mathrm{M} \mathrm{NaCl}+0.044 \mathrm{M} \mathrm{Na}_{2} \mathrm{SO}_{4}\right)$ aqueous solution.

The decrease in the free potential to approximately $-0.4 \mathrm{~V} / \mathrm{SCE}$ was observed for all the corrosion fatigue tests leading to crack initiation. No free potential decrease was observed for 
specimens which did not fail after $10^{7}$ cycles under a stress amplitude equal to the median fatigue strengths in the aqueous solution $\left(\sigma_{R=-1}^{\mathrm{D}}(\mathrm{NaCl})\right.$ or $\left.\sigma_{R=0.1}^{\mathrm{D}}(\mathrm{NaCl})\right)$. Ebara [10] obtained similar results for corrosion fatigue crack initiation tests with $12 \%$ chromium stainless steel in a $3 \% \mathrm{NaCl}$ aqueous solution and observed a relation between the stress amplitude and the potential decrease. The higher the stress amplitude, the lower the initiation time of the potential decrease was for Ebara's tests [10] (Figure 8.a). At relatively low stress amplitudes $\left(\sim 0.22 x \sigma_{\mathrm{u}}\right.$, for the steel studied by Ebara [10]), a potential decrease was not observed. A similar phenomenon is observed in our study with the relation between normalised stress amplitude and the duration of potential decrease (Figure 8.b). For the martensitic stainless steel studied in this work, it is shown hereafter that this continued decline of the metal potential, which is more pronounced at higher stress amplitudes, is attributed to the destruction of the protective (passive) film in solutions with and without chloride.

\section{Electrochemical impedance spectroscopy (EIS) measurement during fatigue tests}

Usually equivalent circuit modelling of the EIS data is used to extract physical properties of the electrochemical system by modelling the impedance data in terms of an equivalent electrical circuit. A resistance in parallel with a capacitance was classically considered, in particular to investigate the high frequency domain of electrochemical impedance measurements. The low frequencies of EIS were investigated by such mechanisms as adsorption or diffusion processes with low time constants. Because we are dealing with a real system that does not behave ideally (processes that occur are distributed in time and space), specialised circuit elements are usually considered. These include a constant phase element (CPE) that accounts for the spatial distribution of the capacitances on the electrode surface [8, 11]. The equivalent circuit chosen for modelling the electrochemical process occurring in the investigated frequency range is shown in Figure 9. The impedance model consists of a solution resistance " $\mathrm{R}_{\mathrm{s}}$ " in series with a capacitance "CPE" in parallel with a charge-transfer resistance " $\mathrm{R}_{\mathrm{ct}}$ " (Figure 9). The EIS data are most often represented in Nyquist or Bode diagrams. A complex plane or Nyquist plot depicts the imaginary impedance, which indicates the capacitive and inductive characteristics of the cell versus the real impedance of the cell. In Nyquist plots, the time-constant appears as an impedance arc in the relatively high frequency domain of the imposed alternative current $(100 \mathrm{~Hz}$ to $0.1 \mathrm{~Hz})$. The curve provides insight into the governing phenomena of the Faraday's reaction, or redox reaction, in this frequency domain (Figure 10). 
During the corrosion fatigue tests, electrochemical impedance spectroscopy analyses were carried out every $30 \mathrm{~min}\left(2.16 \times 10^{5}\right.$ cycles at $\left.120 \mathrm{~Hz}\right)$. The EIS investigation was performed at a zero current value corresponding to the free potential. The Nyquist plots are reported in Figure 10. All diagrams exhibit a capacitive response characterised by the first part of a half circle. A fitting program (Zsimwin) was used to provide the coefficient values of the CPE, $\mathrm{R}_{\mathrm{ct}}$ and $\mathrm{R}_{\mathrm{s}}$. Figure 10 shows that the calculated curves agree with the experimental values in the investigated frequency range. To understand such behaviour, the fitted values of the resistances and the capacitance are plotted in Figure 11. Two regimes were clearly observed: one without cyclic stress and one with cyclic stress. In the regime without cyclic stress, a very high resistance and a weak capacitance were measured. This result denotes the presence of resistance from a protective passive film. After the cyclic stress is applied, the resistance strongly decreases and the capacitance increases. This result shows that the material is more conductive due to a local rupture of the passive film. In this case, the measured resistance corresponds to the electronic charge transfer process of the metal dissolution [12, 13]. Additionally, the corrosive attack on the surface of all the specimens tested in corrosion fatigue was observed in small areas scattered all over the specimen surface. There was no generalised corrosion.

\section{Corrosion fatigue crack initiation mechanism}

The previous analysis and observations are physical evidence that corrosion fatigue crack initiation in the $\mathrm{X} 12 \mathrm{CrNiMoV} 12-3$ stainless steel is related to the local fracture of the passive film due to strain from the applied cyclic stress. These local ruptures of the passive film and the shift of the free potential in the $0.1 \mathrm{M} \mathrm{Na}_{2} \mathrm{SO}_{4}$ and $\left(0.1 \mathrm{M} \mathrm{NaCl}+0.044 \mathrm{M} \mathrm{Na}_{2} \mathrm{SO}_{4}\right)$ aqueous solutions can be associate to (i) the variation in the passive film thickness and/or (ii) the appearance of localize de formation features at the surface of the specimens during fatigue testing. Auger probe measurements of the passive film thickness were carried out on the X12CrNiMoV12-3 specimens. Measurements were performed at ten different locations on the specimen surface in order to evaluate the thickness uniformity of the passive film. The thickness of the passive film is deduced from the typical measurement illustrated Figure 12 and was found to be uniform on the specimen surface. Its value is approximately $3 \mathrm{~nm}$ for the passive film formed in air and $7 \mathrm{~nm}$ for the passive film formed in the $(0.1 \mathrm{M} \mathrm{NaCl}+0.044 \mathrm{M}$ $\mathrm{Na}_{2} \mathrm{SO}_{4}$ ) aqueous solution. This demonstrates that the aqueous media does not dissolve the passive film. 
According to Cretegny et al. [14], several localized deformation processes can be observed on a similar high strength martensitic stainless steel (PH 13-8 Mo martensitic stainless steel) under cyclic loading. First, at low strain amplitudes $(0.4 \%)$ so called "streaks" developing in the form of narrow lines at the surface of fatigued specimens. Such "streaks" have a typical depth of 4 to $5 \mathrm{~nm}$. Secondly at higher strain levels (0,6\% and above) PSB start to develop with typical high between 10 and $200 \mathrm{~nm}$. In all cases the height/depth of deformation features are greater than passive film thickness. Evidences of such deformation processes ("streaks" and PSB) on our material was not as clearly observed as in [14] probably due to the fact that the stress/strain levels are lower in our case leading to much more scattered in space and lower in intensity localized plasticity that makes its observation more difficult. However, the authors believe that similar processes occur on our material. Thus, it is believed that the localized plastic deformations induce strong incompatibilities between the bulk and the passive film that cannot be accommodates by the later. This results in local passive film failure that initiates the corrosion process. A schematic illustration of this corrosion fatigue process is illustrated Figure 13. In this process, stress level (amplitude and mean value) and loading frequency play an important role in maintaining the depassivation of the material.

\section{About the loading frequency}

The possible effect of the loading frequency in corrosion fatigue is related to the repassivation rate after local ruptures in the passive film. The repassivation rate of the $\mathrm{X} 12 \mathrm{CrNiMoV} 12-3$ stainless steel was determined by studying the evolution of the free potential after depassivation under cyclic stress in a corrosive environment with $0.1 \mathrm{M} \mathrm{NaCl}$ and $0.044 \mathrm{M}$ $\mathrm{Na}_{2} \mathrm{SO}_{4}$. Figure 14 shows the evolution of the free potential during the depassivation due to the cyclic loading (under $\sigma_{\mathrm{a}} / \sigma_{\mathrm{u}}=0.28, \mathrm{R}=0.1$ and $\mathrm{f}=120 \mathrm{~Hz}$ ) and repassivation without cyclic loading $(\sigma(t)=0 \mathrm{MPa})$ in the aqueous solution $\left(0.1 \mathrm{M} \mathrm{NaCl}+0.044 \mathrm{M} \mathrm{Na}_{2} \mathrm{SO}_{4}\right)$. The free potential needs approximately 3 days to reach $+0.1 \mathrm{~V} / \mathrm{SCE}$. It is clear that the repassivation rate is significantly lower than the characteristic time of the strain from the applied cyclic stress at a loading frequency of $120 \mathrm{~Hz}$ (characteristic time is $1 / 120=8.3 \mathrm{~ms}$ ). This finding is in agreement with the S-N curves between $10^{5}$ and $10^{7}$ cycles at $10 \mathrm{~Hz}$ and $120 \mathrm{~Hz}$ given in Figure 15. This result shows that the loading frequency (at $10 \mathrm{~Hz}$ and $120 \mathrm{~Hz}$ ) has no significant effect in the aqueous solution. 


\section{Conclusion and prospects}

In this paper, the fatigue crack initiation process of $\mathrm{X} 12 \mathrm{CrNiMoV} 12-3$ stainless steel in air at $120 \mathrm{~Hz}$ was identified. It was also shown that there is a significant decrease in the fatigue strength (in the HCF regime) under corrosion for all the aqueous environments investigated at $120 \mathrm{~Hz}\left(0.1 \mathrm{M} \mathrm{NaCl}+0.044 \mathrm{M} \mathrm{Na}_{2} \mathrm{SO}_{4}, 0.1 \mathrm{M} \mathrm{Na}_{2} \mathrm{SO}_{4}\right.$ and distilled water $)$ compared to the fatigue strength under corrosion in the air. The electrochemical behaviour of the X12CrNiMoV12-3 stainless steel was studied to identify the effect of cyclic stress on the passive film. The potential decreased tremendously, by about $-0.4 \mathrm{~V} / \mathrm{SCE}$, when the strain was applied in all the aqueous environments investigated $\left(0.1 \mathrm{M} \mathrm{NaCl}+0.044 \mathrm{M} \mathrm{Na}_{2} \mathrm{SO}_{4}\right.$ and $1 \mathrm{M} \mathrm{Na}_{2} \mathrm{SO}_{4}$ ). This phenomenon was related to the fracture of the surface passive film identified by the EIS measurements. However, at relatively low normalised stress amplitudes $\left(\sigma_{\mathrm{a}} / \sigma_{\mathrm{u}}=0.17\right.$ for $\mathrm{R}=0.1$ and $\sigma_{\mathrm{a}} / \sigma_{\mathrm{u}}=0.31$ for $\left.\mathrm{R}=-1\right)$, the potential decrease was not observed and there was no crack initiation after $10^{7}$ cycles. It can be concluded that at very low stress amplitudes, the passive film is stable and protects the material against corrosion (up to $10^{7}$ cycles at least). Based on this physical evidence, a scenario for corrosion fatigue crack initiation mechanisms is proposed. In this process, stress level (amplitude and mean value) and loading frequency have important roles in maintaining the depassivation of the material. Furthermore, it has been shown that for $\mathrm{R}=-1$, the loading frequency ranging from $10 \mathrm{~Hz}$ to $120 \mathrm{~Hz}$ has no appreciable effect on the corrosion fatigue crack initiation life in the $(0.1 \mathrm{M}$ $\mathrm{NaCl}+0.044 \mathrm{M} \mathrm{Na}_{2} \mathrm{SO}_{4}$ ) aqueous solution (Figure 15)

This study will be completed by a systematic study of the effect of loading frequency on the corrosion fatigue crack initiation mechanism through a larger frequency range. In the future, a corrosion fatigue crack initiation model considering the coupling between the environment and cyclic loading should also be developed.

\section{Acknowledgments}

This work was carried out in the framework of the ARCAM project, with the financial support of DGCIS, and Aquitaine, Auvergne and Midi-Pyrénées French regions. The authors thankfully acknowledge the industrial partners for the project, including Ratier-Figeac, Aubert et Duval, Olympus, and the academic partners at the Material Department of ICAM and the CIRIMAT (Toulouse University, France). 


\section{References}

[1] Y. Kondo, "Prediction of fatigue crack initiation life based on pit growth", Corrosion Vol. 45, pp. 7-11, (1979)

[2] S. Xu, X.Q. Wu, E.H. Han, W. Ke and Y. Katada "Crack initiation mechanisms for low cycle fatigue of type 316Ti stainless steel in High temperature water", Mat. Sci. and Eng. A, Vol. 490, pp. 16-25 (2008)

[3] C. Laird and D. J. Duquette, "Mechanisms of fatigue crack nucleation", In Corrosion fatigue: chemistry, mechanics and microstructure, O. Devereux, A.J. McEvily and R.W. Stachle Editors, Nat. Ass. Corr. Engng (NACE) - 2, p. 88, (1973)

[4] R. Pelloux and J.-M. Genkin "Chapitre 10: Fatigue-corrosion", in C. Bathias and A. Pineau, "Fatigue des matériaux et des structures", Vol. 2, Ed. Hermès, Paris, pp. 141$152(2008)$

[5] T. Palin-Luc, R. Pérez-Mora, C. Bathias, G. Domínguez, P. C. Paris and J. Luis Aran, "Fatigue crack initiation and growth on a steel in the very high cycle regime with sea water corrosion.”, Engng. Fract. Mech., Vol. 77, pp. 1953-1962, (2010)

[6] R. Ebara, Y. Yamada and A. Goto, "Corrosion fatigue behaviour of $13 \mathrm{Cr}$ stainless steel and Ti-6Al-4V ultrasonic frequency", Fatigue ultrasonore, TMS (1980)

[7] D. J. McAdam, "Corrosion Fatigue of Metals", Jr. Trans. Am. Soc. Steel Treat., 11, pp. 355-79 (1927)

[8] O. Devos, G. Gabrielli and B. Tribollet, "Simultaneous EIS and in situ microscope observation on partially blocked electrode application to scale electrodeposition", Electrochimica Acta, Vol 51, pp. 1413-1422 (2006)

[9] A. Turnbull and S. Zhou, "Comparative evolution of environment induced cracking of conventional and advanced stream turbine blade steels. Part 1: Stress corrosion cracking”, Corrosion Science 52, pp. 2936-2944 (2010)

[10] R. Ebara, "Corrosion fatigue crack initiation in $12 \%$ chromium stainless steel", Material Science and Engineering A, 468-470, pp. 109-113 (2007) 
[11] G. J. Brug, A. L. G. Van Den Eeden, M. Sluyters-Rehbach and J. H. Sluyters, "The analysis of electrode impedances complicated by the presence of a constant phase element", J. Electroanal. Chem., 176, p. 275 (1984)

[12] O. Ferraz, E. Cavalcanti and A.R. Di Sarli, "The characterization of protective properties for some naval steel/polimeric coating/3\% $\mathrm{NaCl}$ solution systems by EIS and visual assessment”, Corrosion Science, Vol. 37, pp. 1267-1280 (1995)

[13] C. Liu, Q. Bi and A. Matthews, "EIS comparison on corrosion performance of PVD TiN and $\mathrm{CrN}$ coated mild steel in $0.5 \mathrm{~N} \mathrm{NaCl}$ aqueous solution", Corrosion Science, Vol 43, pp. 1953-1961 (2001)

[14] L. Cretegny and A. Saxena, "Evolution of surface deformation during fatigue of PH 138 Mo stainless steel using atomic force microscopy", Fatigue Fract. Engng. Mater. Struct. 25, pp. 305-314 (2002) 


\section{List of tables:}

Table 1: Chemical composition of the X12CrNiMoV12-3 stainless steel (wt \%, Fe balance).

Table 2: Mechanical properties of the X12CrNiMoV12-3 stainless steel under monotonic quasi-static tension.

\section{List of figures:}

Figure 1: X12CrNiMoV12-3 stainless steel microstructure after heat treatment . 16

Figure 2: Specimen geometry for (a) fatigue tests in air and (b) corrosion fatigue tests

Figure 3: In-situ corrosion fatigue cell with potentiostatic measurements. The specimen is isolated from the fatigue testing machine (Vibrophore)

Figure 4: Median S-N curves (survival probability Ps $=0.5$ ) in air and in the aqueous solutions at 120 $\mathrm{Hz}$.

Figure 5: Crack initiation sites in air and under corrosion fatigue in the aqueous solutions

Figure 6: Linear scan voltammetry test on a specimen without cyclic stress in $0.1 \mathrm{M} \mathrm{NaCl}+0.044 \mathrm{M}$ $\mathrm{Na}_{2} \mathrm{SO}_{4}$

Figure 7: Free corrosion potential evolution during corrosion fatigue testing of specimen at (a) $R=0.1$ and (b) $R=-1$

Figure 8: Relation between normalized stress amplitude and (a) initiation time of potential decrease from Ebara [9] and (b) duration of the potential decrease for our corrosion fatigue tests.....

Figure 9: Equivalent circuit of impedance diagram $\left(R_{s}\right.$ is the solution resistance, $R_{c t}$ is the chargetransfer resistance and CPE is the constant phase element)

Figure 10: Evolution of the Nyquist plots versus time during corrosion for several durations in $0.1 \mathrm{M}$ $\mathrm{NaCl}+0.044 \mathrm{M} \mathrm{Na}_{2} \mathrm{SO}_{4} ; \sigma_{\mathrm{a}} / \sigma_{\mathrm{u}}=0.23 ; \mathrm{R}=0.1 ; \mathrm{f}=120 \mathrm{~Hz} ; \mathrm{N}_{\mathrm{f}}=9.2 \times 10^{5}$ cycles

Figure 11: Evolution of (a) the charge-transfer resistance and (b) the capacitance (CPE) of the model in Figure 9 prior to cyclic loading and during cyclic loading (the exposed surface is $5 \mathrm{~cm}^{2}$ ) in $0.1 \mathrm{M}$ $\mathrm{NaCl}+0.044 \mathrm{M} \mathrm{Na}_{2} \mathrm{SO}_{4} ; \sigma_{\mathrm{a}} / \sigma_{\mathrm{u}}=0.23 ; \mathrm{R}=0.1 ; \mathrm{f}=120 \mathrm{~Hz} ; \mathrm{N}_{\mathrm{f}}=9.2 \times 10^{5}$ cycles

Figure 12: Results of Auger measurements at the surface of the X12CrMoV12-3 stainless steel with (a) passive film formed in air, (b) passive film formed in $\left(0.1 \mathrm{M} \mathrm{NaCl}+0.044 \mathrm{M} \mathrm{Na}_{2} \mathrm{SO}_{4}\right)$

Figure 13: Scenario of corrosion fatigue crack initiation at pits on the X12CrNiMoV12-3 martensitic stainless steel under a $120 \mathrm{~Hz}$ loading frequency in the HCF regime $\left(10^{5}-10^{7}\right.$ cycles) 
Figure 14: Depassivation by cyclic loading $\left(\sigma_{a} / \sigma_{u}=0.28, R=0.1\right.$ and $\left.f=120 \mathrm{~Hz}\right)$, then repassivation without cyclic loading $(\sigma(t)=0 \mathrm{MPa})$ in corrosion solution $\left(0.1 \mathrm{M} \mathrm{NaCl}+0.044 \mathrm{M} \mathrm{Na}_{2} \mathrm{SO}_{4}\right)$.

Figure 15: Fatigue test results and $\mathrm{S}-\mathrm{N}$ curves of corrosion fatigue tests for two different loading frequencies $(120 \mathrm{~Hz}$ and $10 \mathrm{~Hz})$ at $\mathrm{R}=-1 \ldots$ 
Table 1: Chemical composition of the X12CrNiMoV12-3 stainless steel (wt \%, Fe balance)

\begin{tabular}{|c|c|c|c|c|}
\hline $\mathbf{C}$ & $\mathbf{C r}$ & $\mathbf{N i}$ & $\mathbf{M o}$ & $\mathbf{V}$ \\
\hline 0.12 & 12 & 3 & 1.6 & 0.3 \\
\hline
\end{tabular}

Table 2: Mechanical properties of the X12CrNiMoV12-3 stainless steel under monotonic quasi-static tension

\begin{tabular}{|c|c|c|}
\hline $\mathbf{E}(\mathbf{G P a})$ & $\boldsymbol{\sigma}_{\mathbf{0 . 2}}(\mathbf{M P a})$ & $\mathbf{A}(\boldsymbol{\%})$ \\
\hline 211 & 1040 & 15 \\
\hline
\end{tabular}



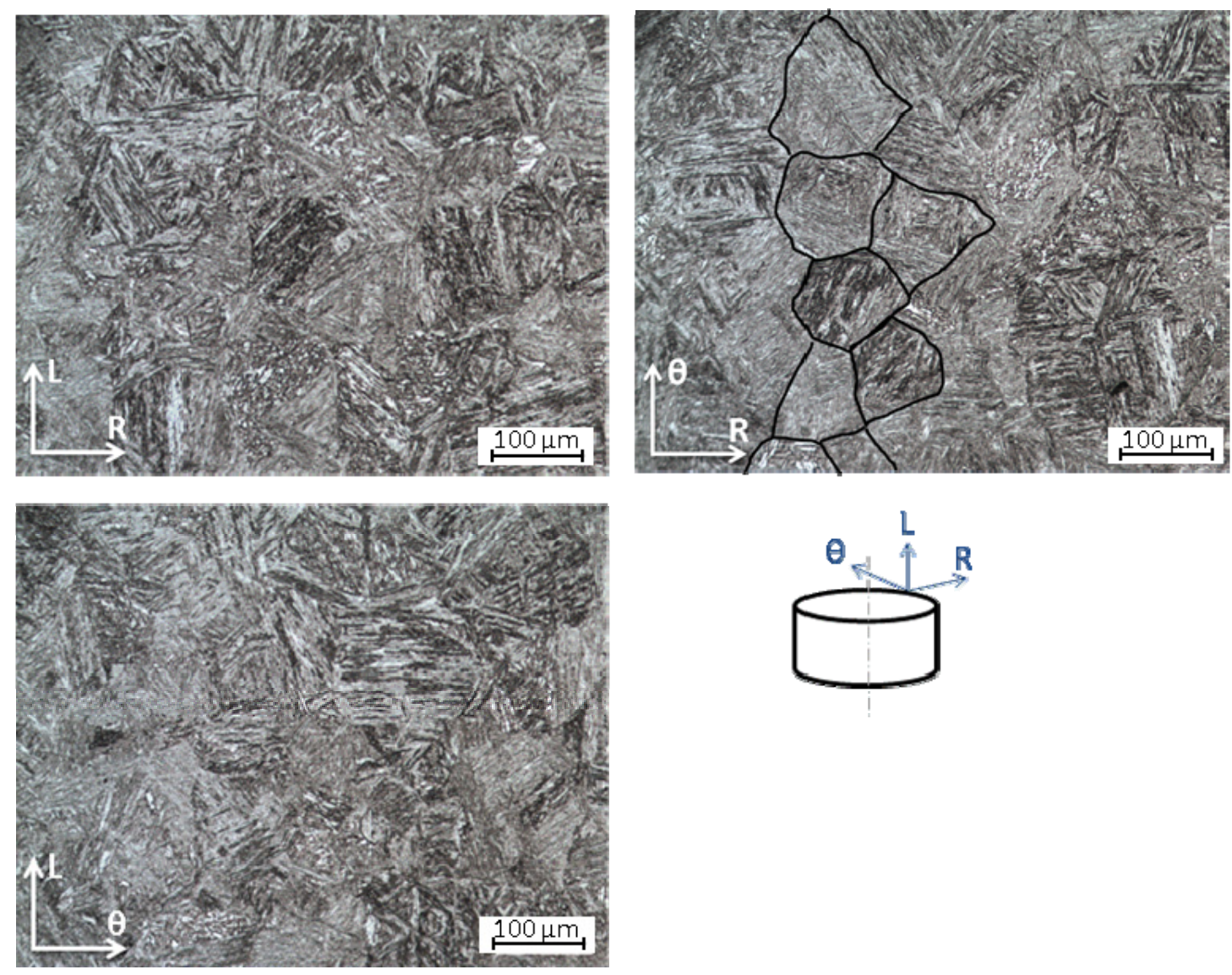

Figure 1: X12CrNiMoV12-3 stainless steel microstructure after heat treatment 


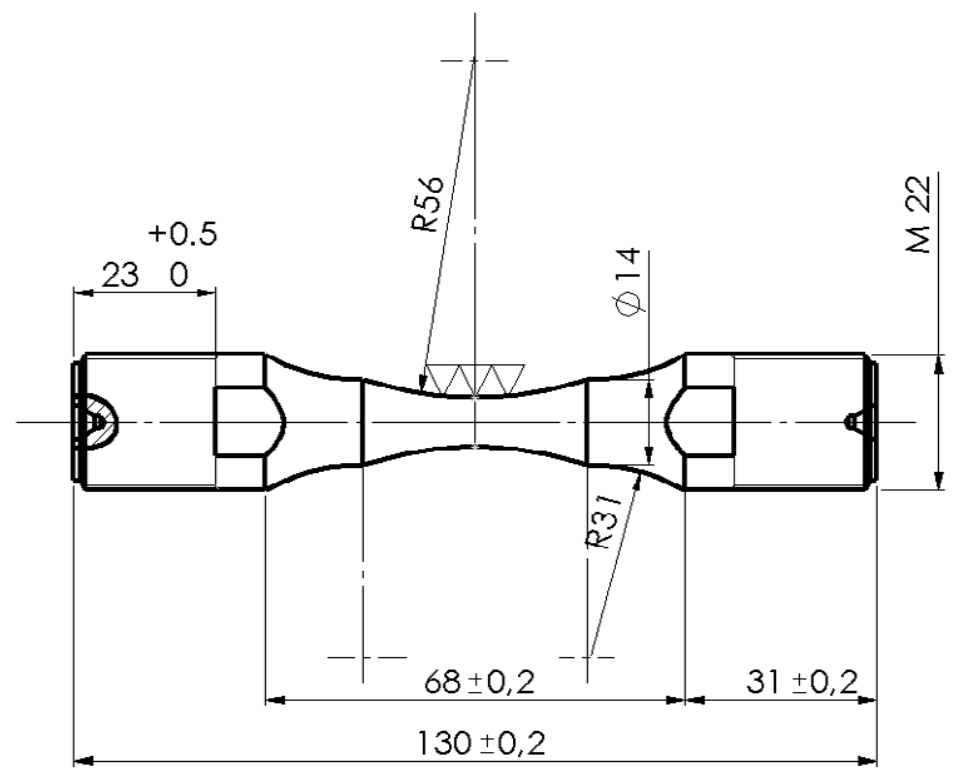

- $W \quad \begin{aligned} & \operatorname{Ra}<=0,1 \mu \mathrm{m} \\ & \operatorname{Rtmax}<=2 \mu \mathrm{m}\end{aligned}$
- $\mathrm{Kt}=1.04$

(a)

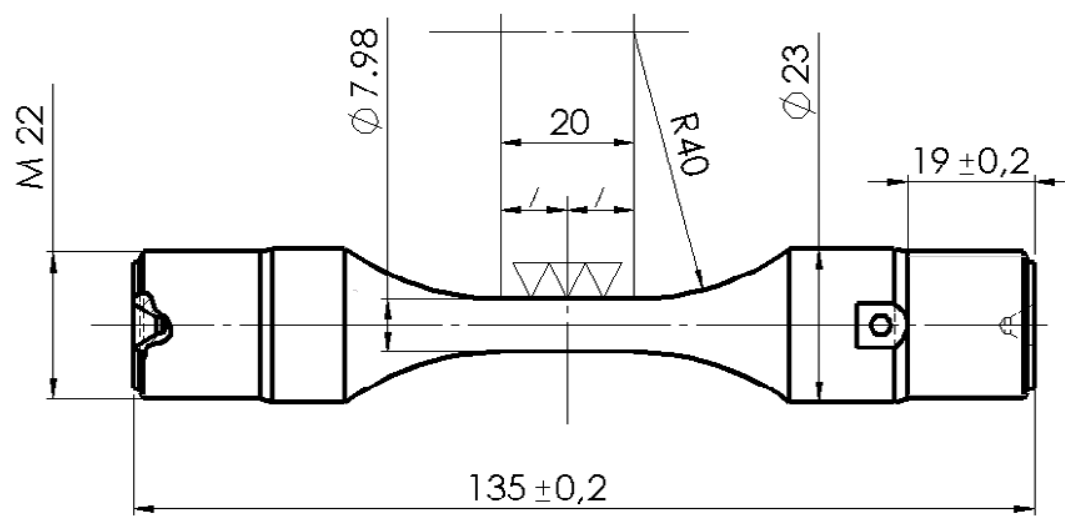

- $W$ Ra $<=0,1 \mu \mathrm{m}$ Rtmax $<=2 \mu \mathrm{m}$

- $\mathrm{Kt}: 1.04$

(b)

Figure 2: Specimen geometry for (a) fatigue tests in air and (b) corrosion fatigue tests 


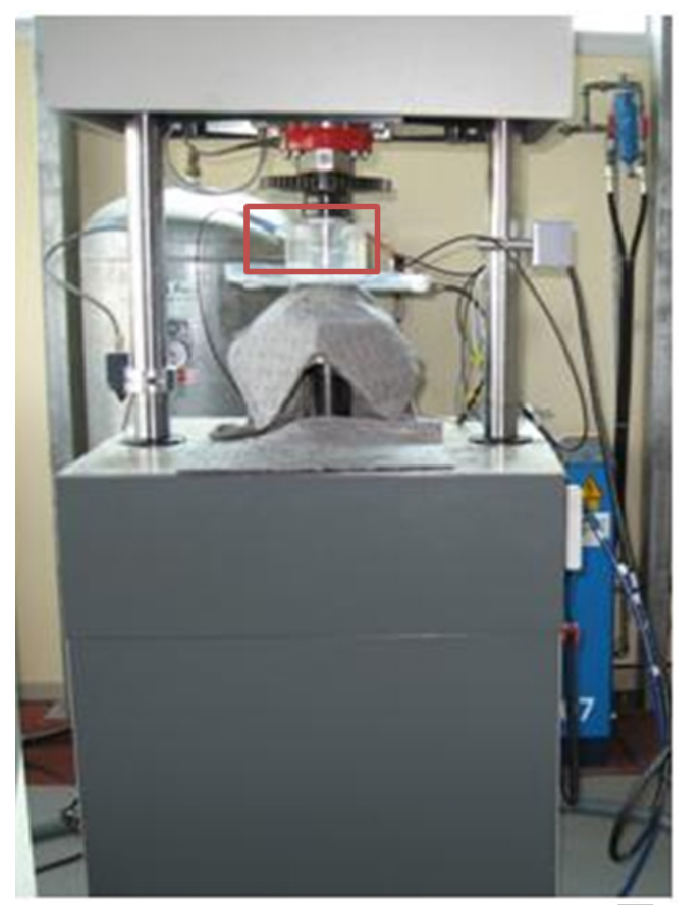

(a)

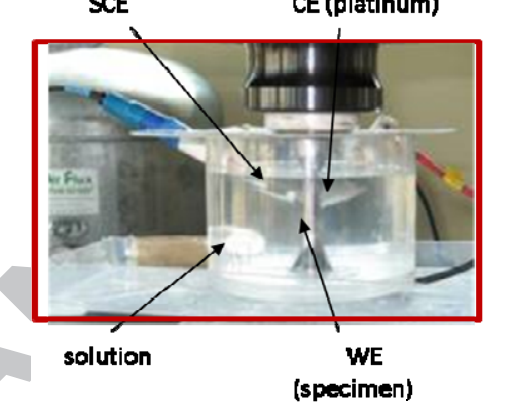

(b)

Figure 3: In-situ corrosion fatigue cell with potentiostatic measurements. The specimen is isolated from the fatigue testing machine (Vibrophore) 


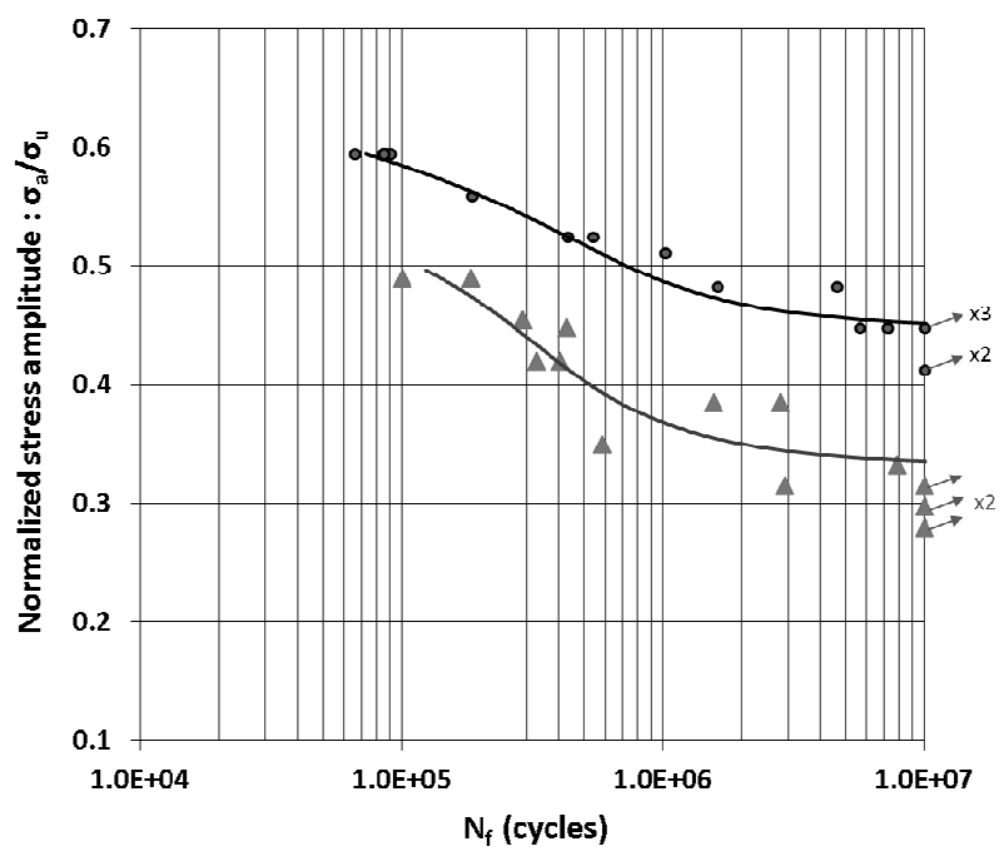

- in air $\quad \Delta$ in $0.1 \mathrm{M} \mathrm{NaCl}+0.044 \mathrm{M} \mathrm{Na} 2 \mathrm{SO} 4$

(a) under fully reversed tension $(\mathrm{R}=-1)$

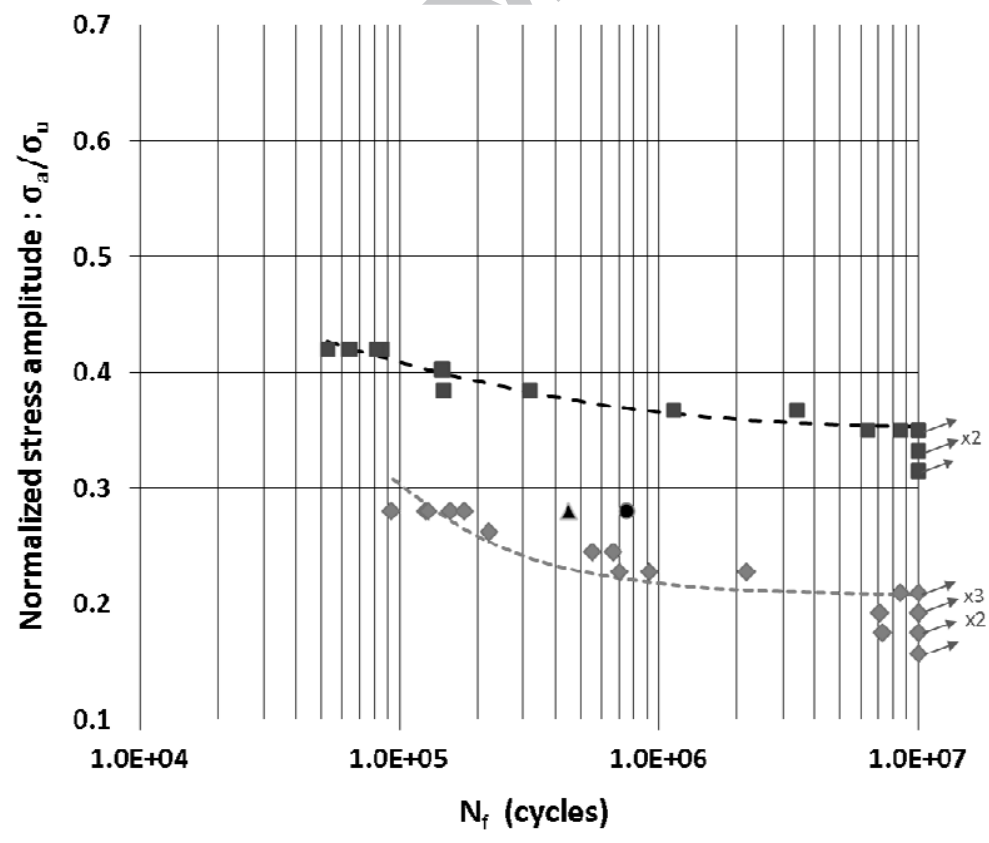

in air

in $0.1 \mathrm{M} \mathrm{NaCl}+0.044 \mathrm{M} \mathrm{Na} 2 \mathrm{SO} 4$

- in distilled water

$\Delta$ in $0.1 \mathrm{M} \mathrm{Na} 2 \mathrm{SO} 4$

(b) under tension-tension $(\mathrm{R}=0.1)$

Figure 4: Median S-N curves (survival probability Ps $=0.5$ ) in air and in the aqueous solutions at $120 \mathrm{~Hz}$ 


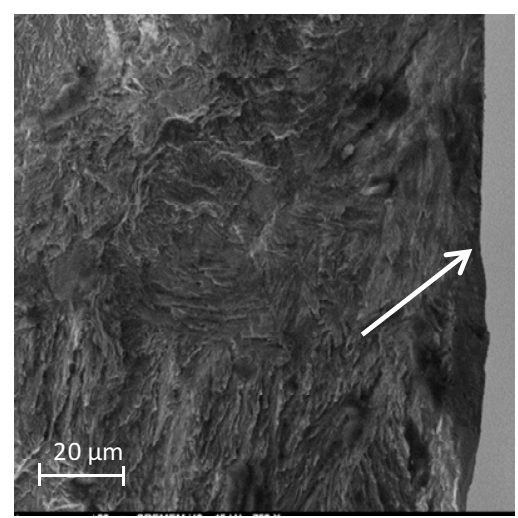

(a) $\sigma_{\mathrm{a}} / \sigma_{\mathrm{u}}=0.52 ; \mathrm{R}=-1$; in air; $\mathrm{N}_{\mathrm{f}}=4.3 \times 10^{5}$ cycles

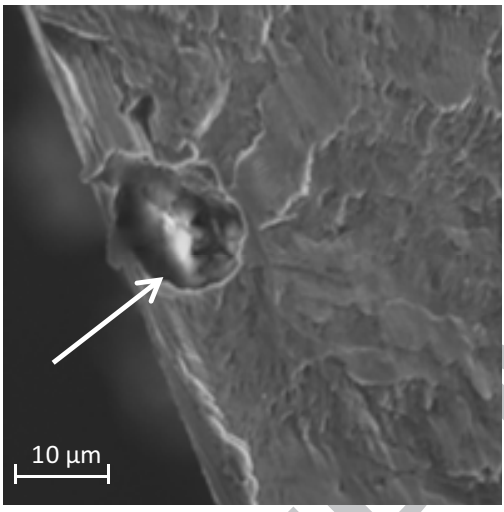

(c) $\sigma_{\mathrm{a}} / \sigma_{\mathrm{u}}=0.45 ; \mathrm{R}=-1$; in $(0.1 \mathrm{M} \mathrm{NaCl}+$ $\left.0.044 \mathrm{M} \mathrm{Na}_{2} \mathrm{SO}_{4}\right) ; \mathrm{N}_{\mathrm{f}}=4.3 \times 10^{5}$ cycles

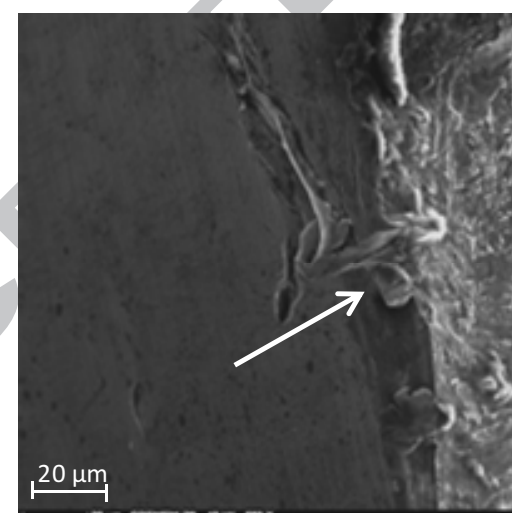

(e) $\sigma_{\mathrm{a}} / \sigma_{\mathrm{u}}=0.28 ; \mathrm{R}=0.1 ;$ in $(0.1 \mathrm{M}$ $\left.\mathrm{Na}_{2} \mathrm{SO}_{4}\right) ; \mathrm{N}_{\mathrm{f}}=4.5 \times 10^{5}$ cycles

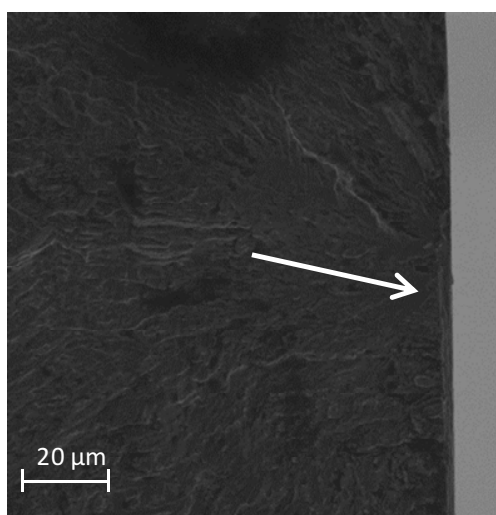

(b) $\sigma_{\mathrm{a}} / \sigma_{\mathrm{u}}=0.42 ; \mathrm{R}=0.1$; in a ir; $\mathrm{N}_{\mathrm{f}}=8.6 \times 10^{4}$ cycles

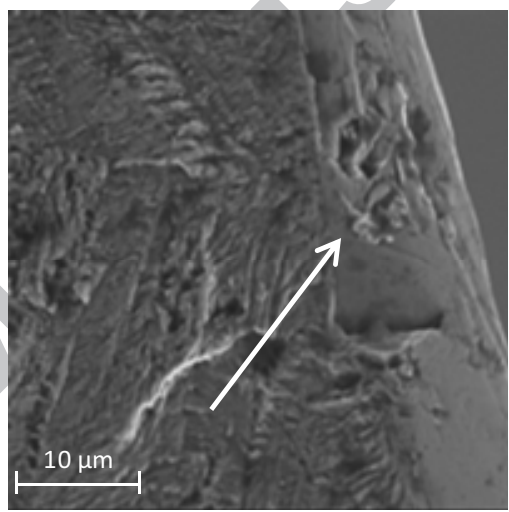

(d) $\sigma_{\mathrm{a}} / \sigma_{\mathrm{u}}=0.23 ; \mathrm{R}=0.1$; in $(0.1 \mathrm{M} \mathrm{NaCl}$ $\left.+0.044 \mathrm{M} \mathrm{Na}_{2} \mathrm{SO}_{4}\right) ; \mathrm{N}_{\mathrm{f}}=9.2 \times 10^{5}$ cycles

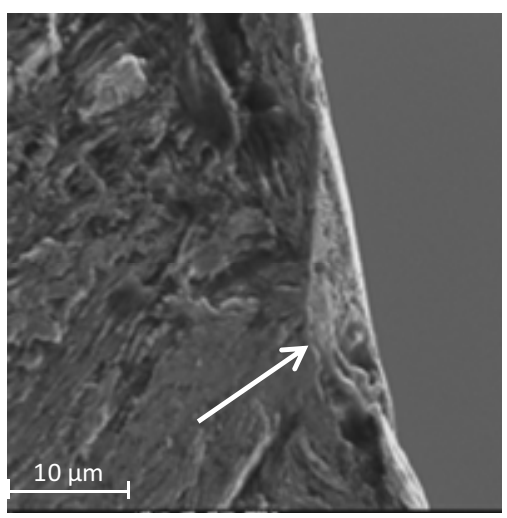

(f) $\sigma_{\mathrm{a}} / \sigma_{\mathrm{u}}=0.28 ; \mathrm{R}=0.1$; in distilled water; $\mathrm{N}_{\mathrm{f}}=7.6 \times 10^{5} \mathrm{cycles}$

Figure 5: Crack initiation sites in air and under corrosion fatigue in the aqueous solutions 


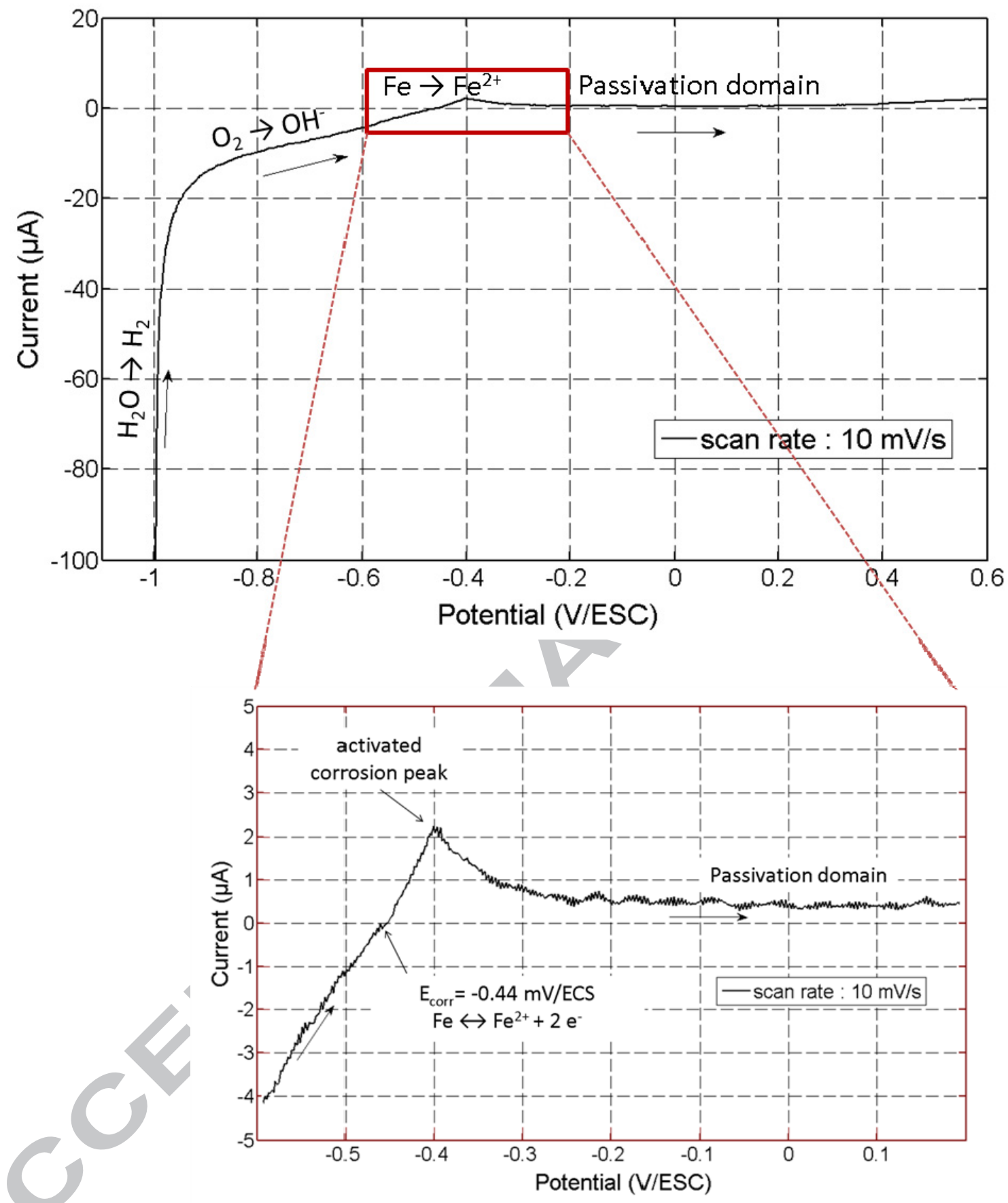

Figure 6: Linear scan voltammetry test on a specimen without cyclic stress in $0.1 \mathrm{M} \mathrm{NaCl}+$ $0.044 \mathrm{M} \mathrm{Na}_{2} \mathrm{SO}_{4}$ 


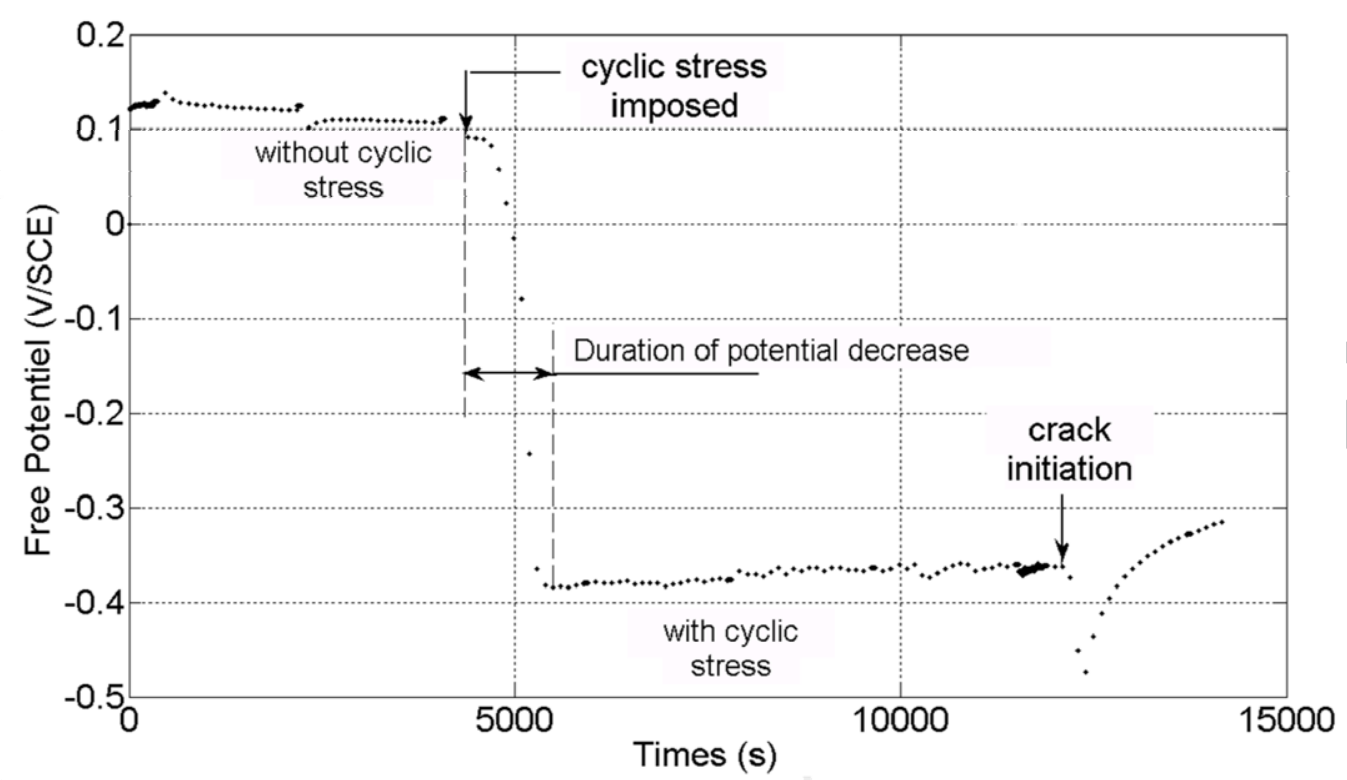

(a) Test at $\mathrm{R}=0.1$; in $0.1 \mathrm{M} \mathrm{NaCl}+0.044 \mathrm{M} \mathrm{Na}_{2} \mathrm{SO}_{4}$; under $\sigma_{\mathrm{a}} / \sigma_{\mathrm{u}}=0.23 ; \mathrm{f}=120 \mathrm{~Hz}$; $\mathrm{N}_{\mathrm{f}}=9.2 \times 10^{5}$ cycles

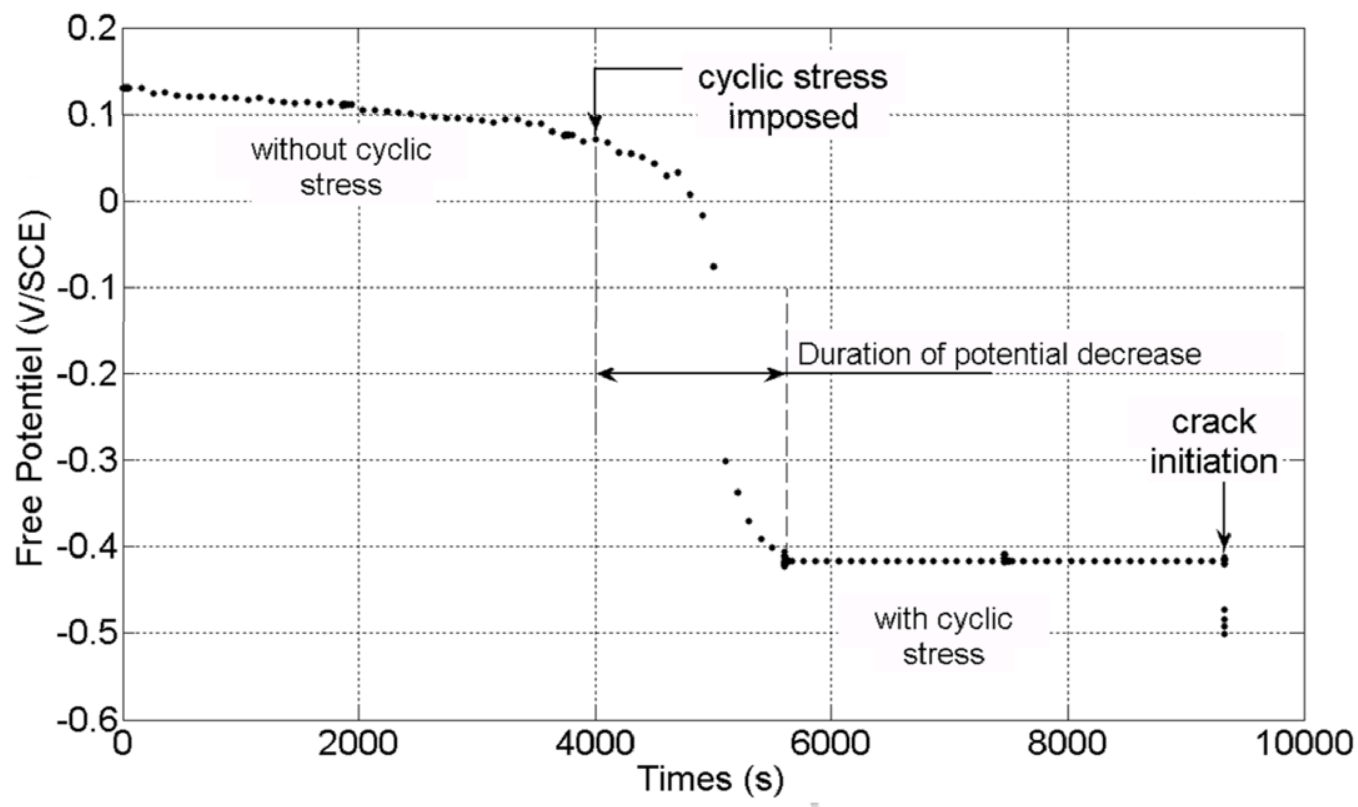

(b) Test at $\mathrm{R}=-1$; in $0.1 \mathrm{M} \mathrm{NaCl}+0.044 \mathrm{M} \mathrm{Na}_{2} \mathrm{SO}_{4} ; \sigma_{\mathrm{a}} / \sigma_{\mathrm{u}}=0.45 ; \mathrm{f}=120 \mathrm{~Hz}$;

$$
\mathrm{N}_{\mathrm{f}}=4.3 \times 10^{5} \text { cycles }
$$

Figure 7: Free corrosion potential evolution during corrosion fatigue testing of specimen at (a)

$$
\mathrm{R}=0.1 \text { and (b) } \mathrm{R}=-1
$$




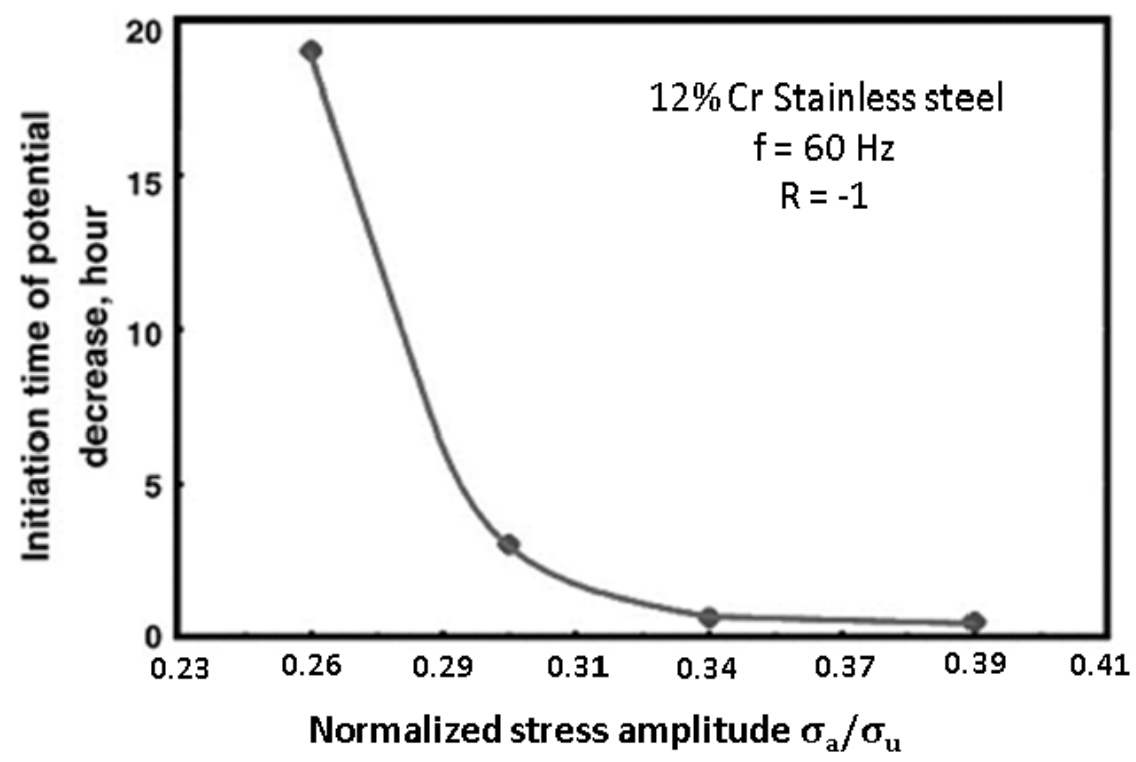

(a)

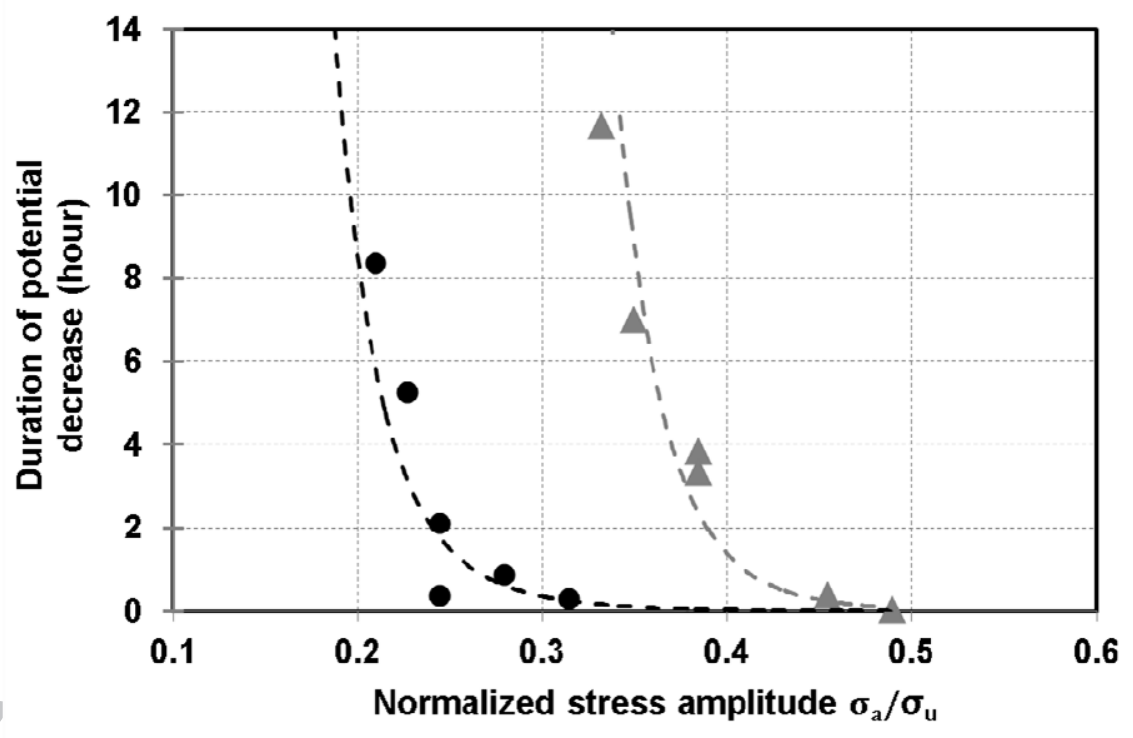

$\Delta$ corrosion fatigue tests at $\mathrm{R}=-1$ in $(0.1 \mathrm{M} \mathrm{NaCl}+0.044 \mathrm{M} \mathrm{Na} 2 \mathrm{SO} 4)$

- corrosion fatigue tests at $\mathrm{R}=0.1$ in $(0.1 \mathrm{M} \mathrm{NaCl}+0.044 \mathrm{M} \mathrm{Na} 2 \mathrm{SO} 4)$

(b)

Figure 8: Relation between normalized stress amplitude and (a) initiation time of potential decrease from Ebara [9] and (b) duration of the potential decrease for our corrosion fatigue tests 


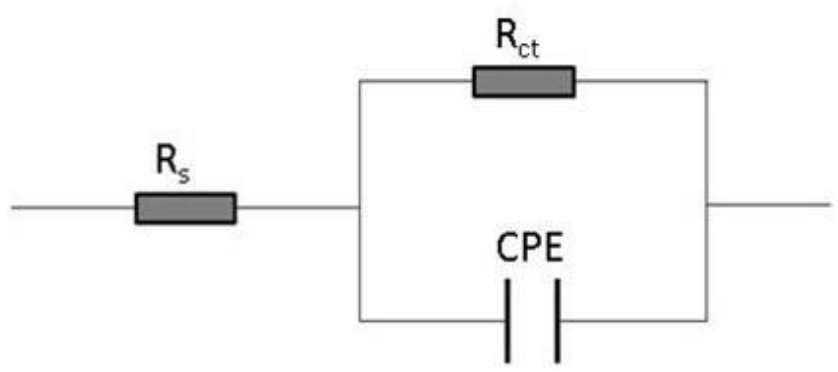

Figure 9: Equivalent circuit of impedance diagram $\left(R_{s}\right.$ is the solution resistance, $R_{c t}$ is the charge-transfer resistance and CPE is the constant phase element) 


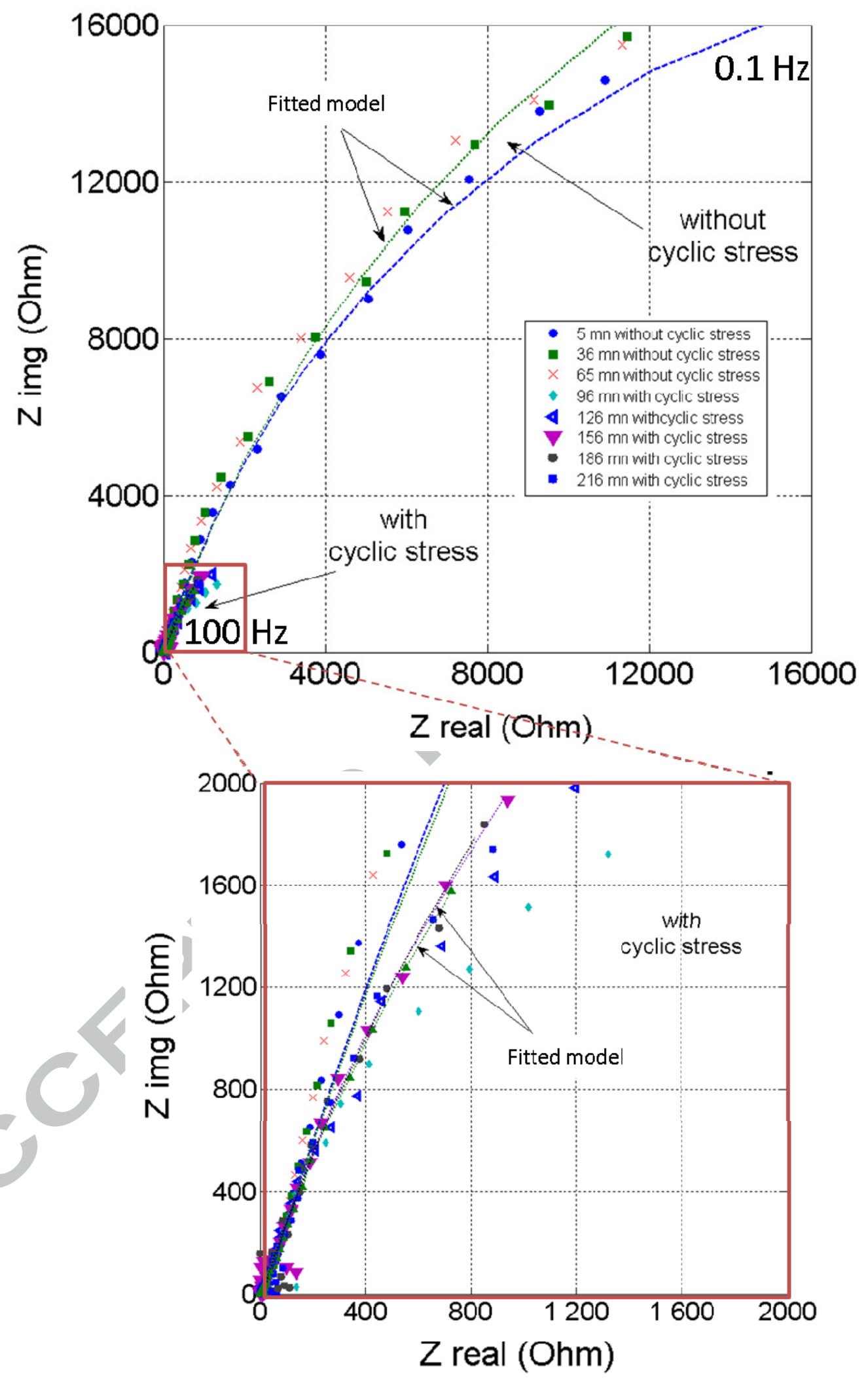

Figure 10: Evolution of the Nyquist plots versus time during corrosion for several durations in $0.1 \mathrm{M} \mathrm{NaCl}+0.044 \mathrm{M} \mathrm{Na}_{2} \mathrm{SO}_{4} ; \sigma_{\mathrm{a}} / \sigma_{\mathrm{u}}=0.23 ; \mathrm{R}=0.1 ; \mathrm{f}=120 \mathrm{~Hz} ; \mathrm{N}_{\mathrm{f}}=9.2 \times 10^{5}$ cycles 


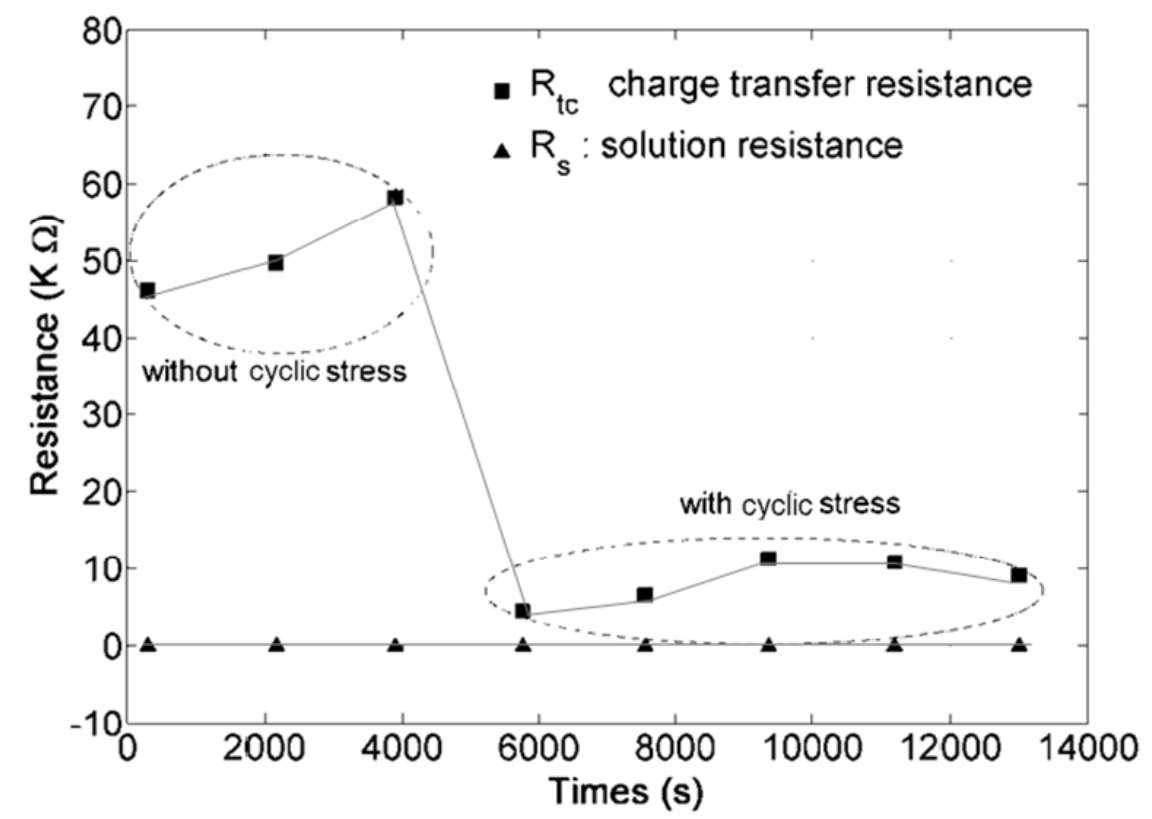

(a)

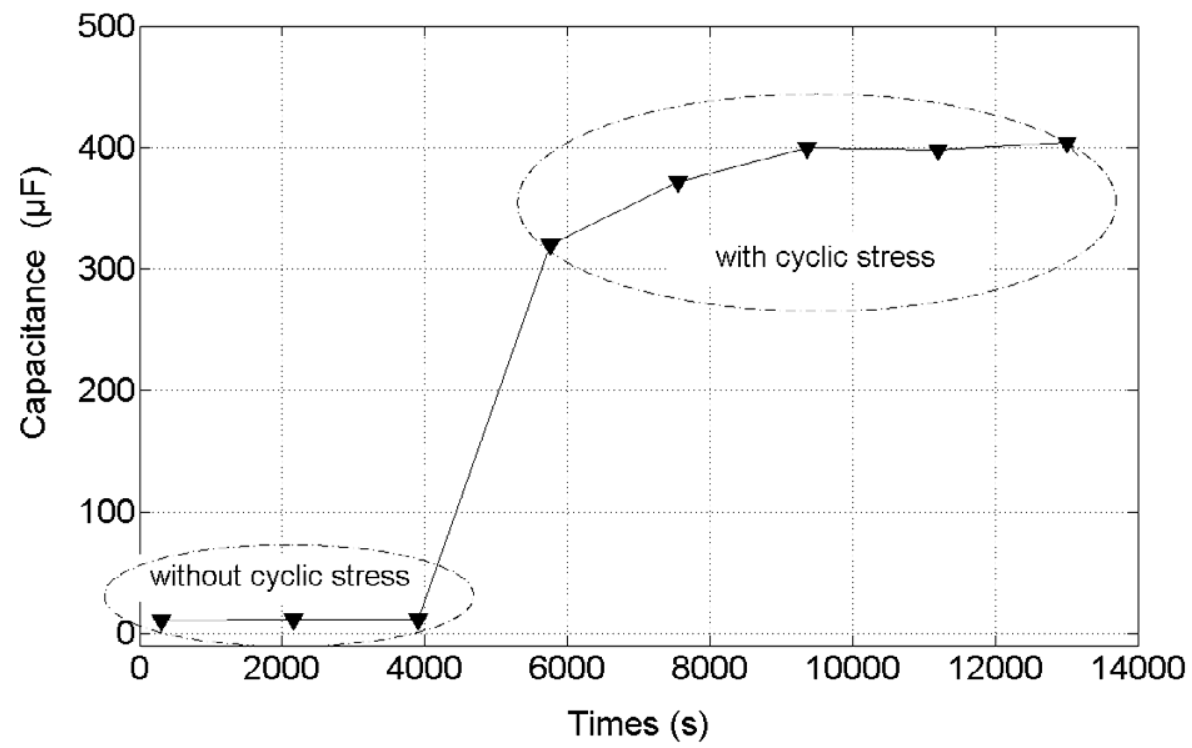

(b)

Figure 11: Evolution of (a) the charge-transfer resistance and (b) the capacitance (CPE) of the model in Figure 9 prior to cyclic loading and during cyclic loading (the exposed surface is $5 \mathrm{~cm}^{2}$ ) in $0.1 \mathrm{M} \mathrm{NaCl}+0.044 \mathrm{M} \mathrm{Na}_{2} \mathrm{SO}_{4} ; \sigma_{\mathrm{a}} / \sigma_{\mathrm{u}}=0.23 ; \mathrm{R}=0.1 ; \mathrm{f}=120 \mathrm{~Hz}$;

$$
\mathrm{N}_{\mathrm{f}}=9.2 \times 10^{5} \text { cycles }
$$




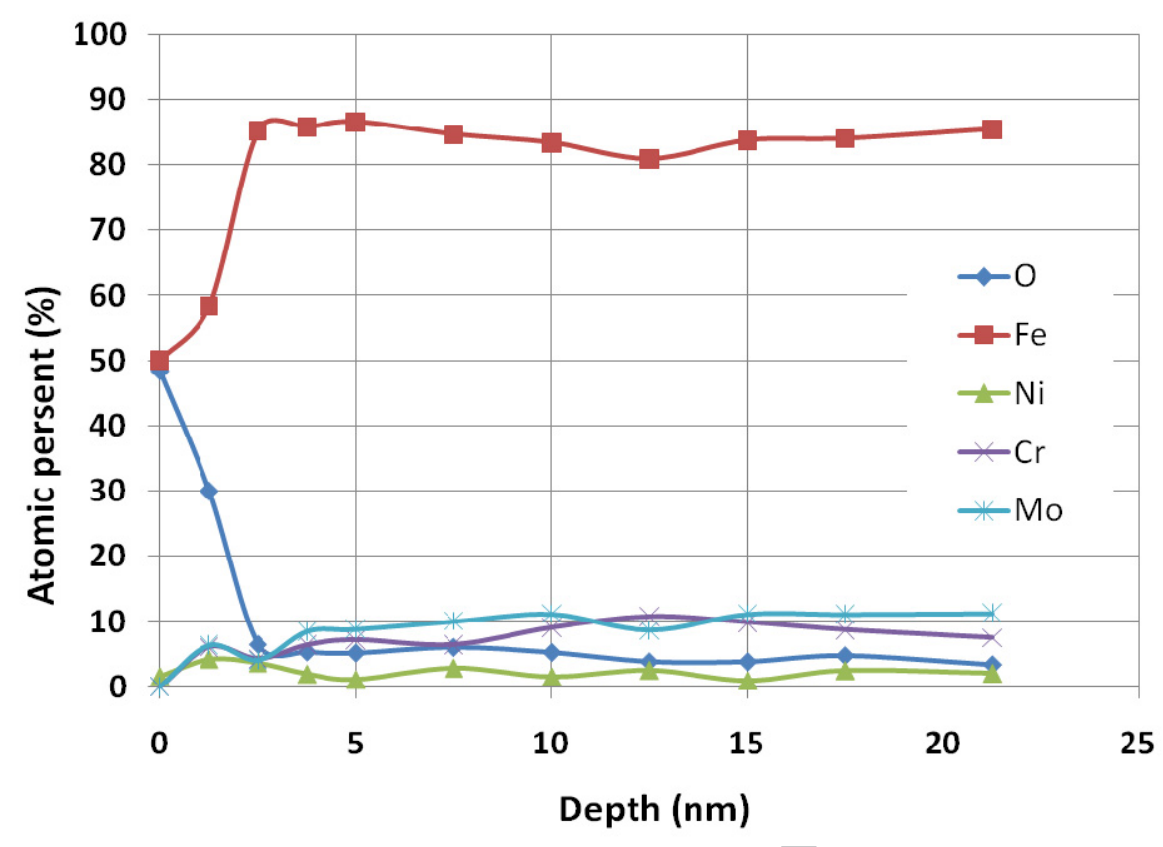

(a)

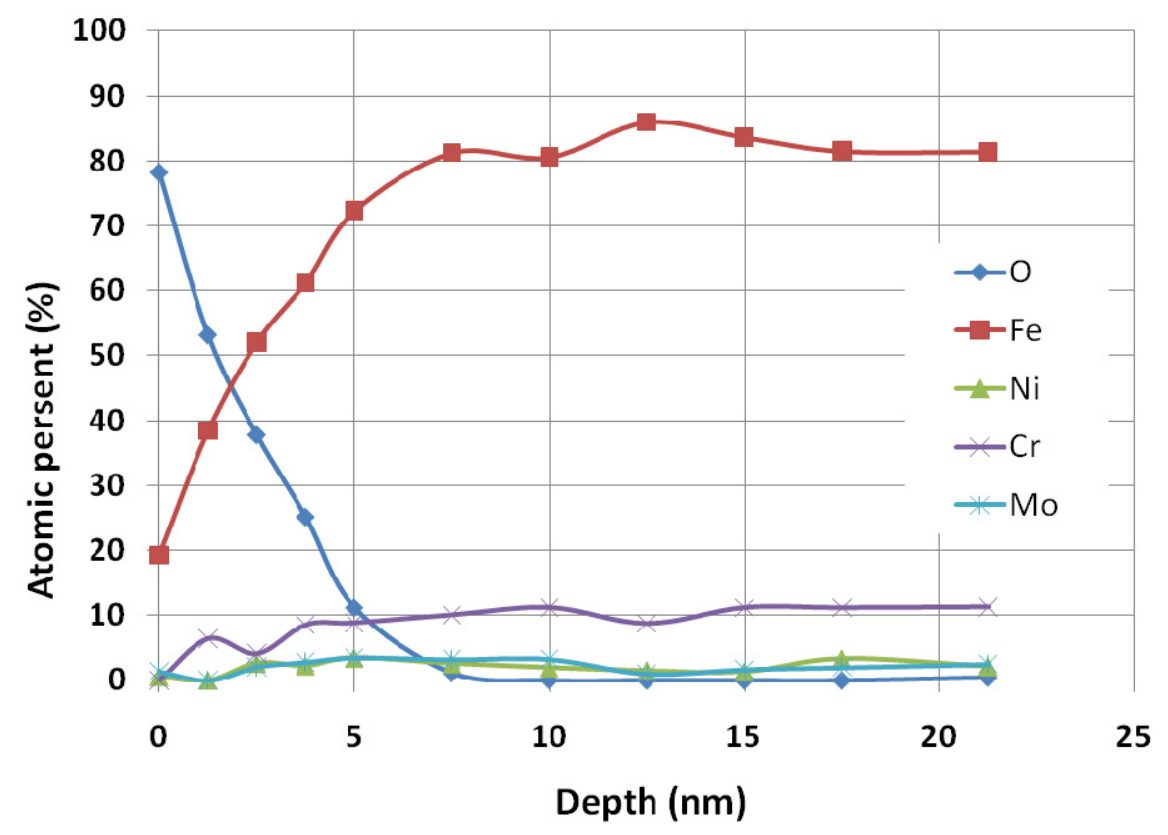

(b)

Figure 12: Results of Auger measurements at the surface of the X12CrMoV12-3 stainless steel with (a) passive film formed in air, (b) passive film formed in $(0.1 \mathrm{M} \mathrm{NaCl}+0.044 \mathrm{M}$ $\mathrm{Na}_{2} \mathrm{SO}_{4}$ ) 


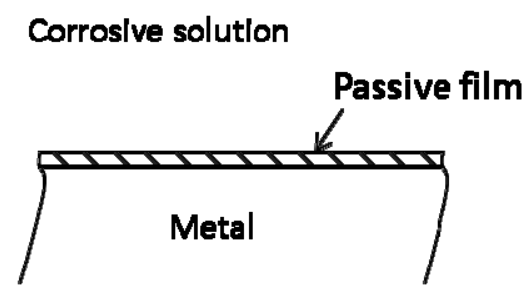

(a) Stable passive film

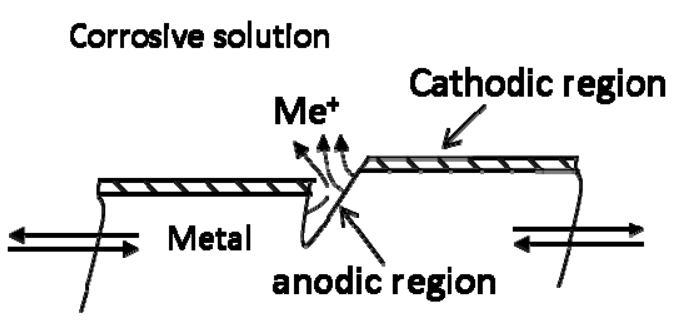

\section{(c) Free metal dissolution In corroslve solution}

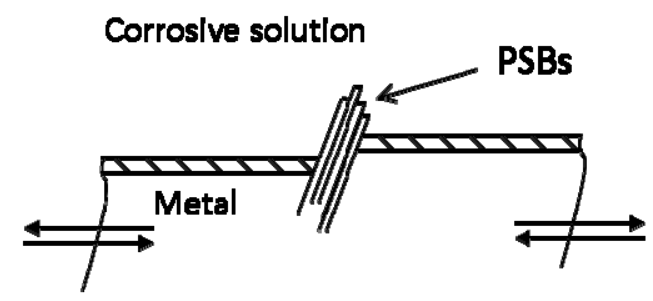

(b) Fracture of passlve film by PSB

Corrosive solution

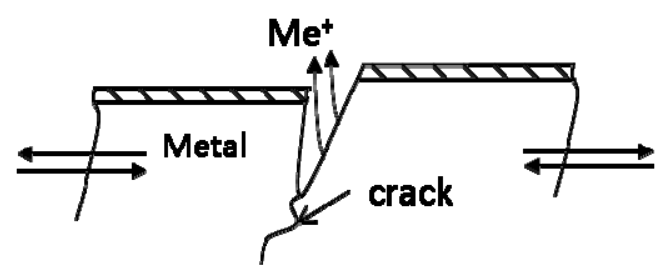

(d) Crack Inltlatlon at corrosion defect

\section{$\stackrel{\longrightarrow}{\longleftrightarrow}$ Cyclic stress}

Figure 13: Scenario of corrosion fatigue crack initiation at pits on the X12CrNiMoV12-3 martensitic stainless steel under a $120 \mathrm{~Hz}$ loading frequency in the HCF regime $\left(10^{5}-10^{7}\right.$ cycles) 


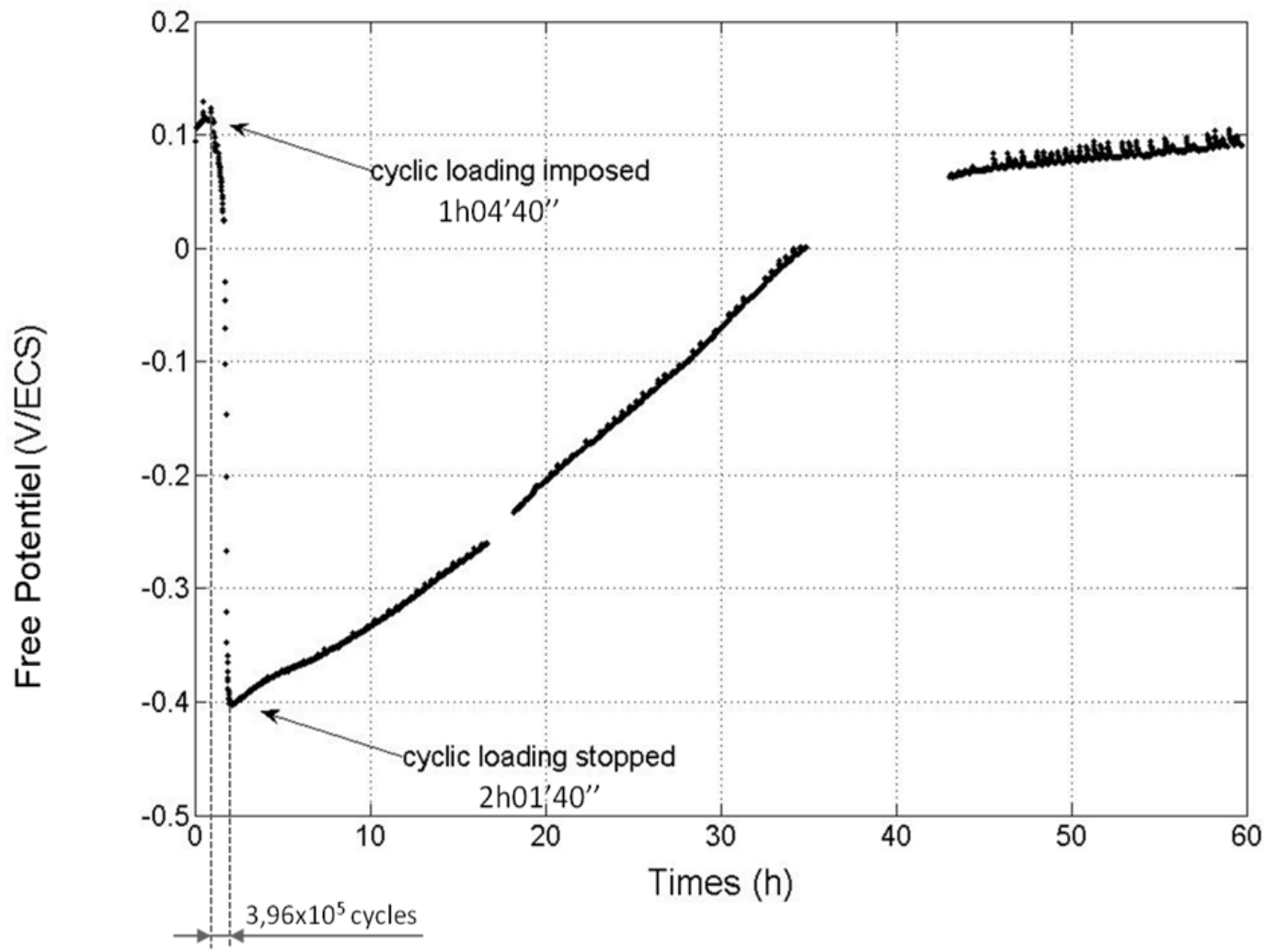

Figure 14: Depassivation by cyclic loading $\left(\sigma_{\mathrm{a}} / \sigma_{\mathrm{u}}=0.28, \mathrm{R}=0.1\right.$ and $\left.\mathrm{f}=120 \mathrm{~Hz}\right)$, then repassivation without cyclic loading $(\sigma(\mathrm{t})=0 \mathrm{MPa})$ in corrosion solution $(0.1 \mathrm{M} \mathrm{NaCl}+$ $\left.0.044 \mathrm{M} \mathrm{Na}_{2} \mathrm{SO}_{4}\right)$ 


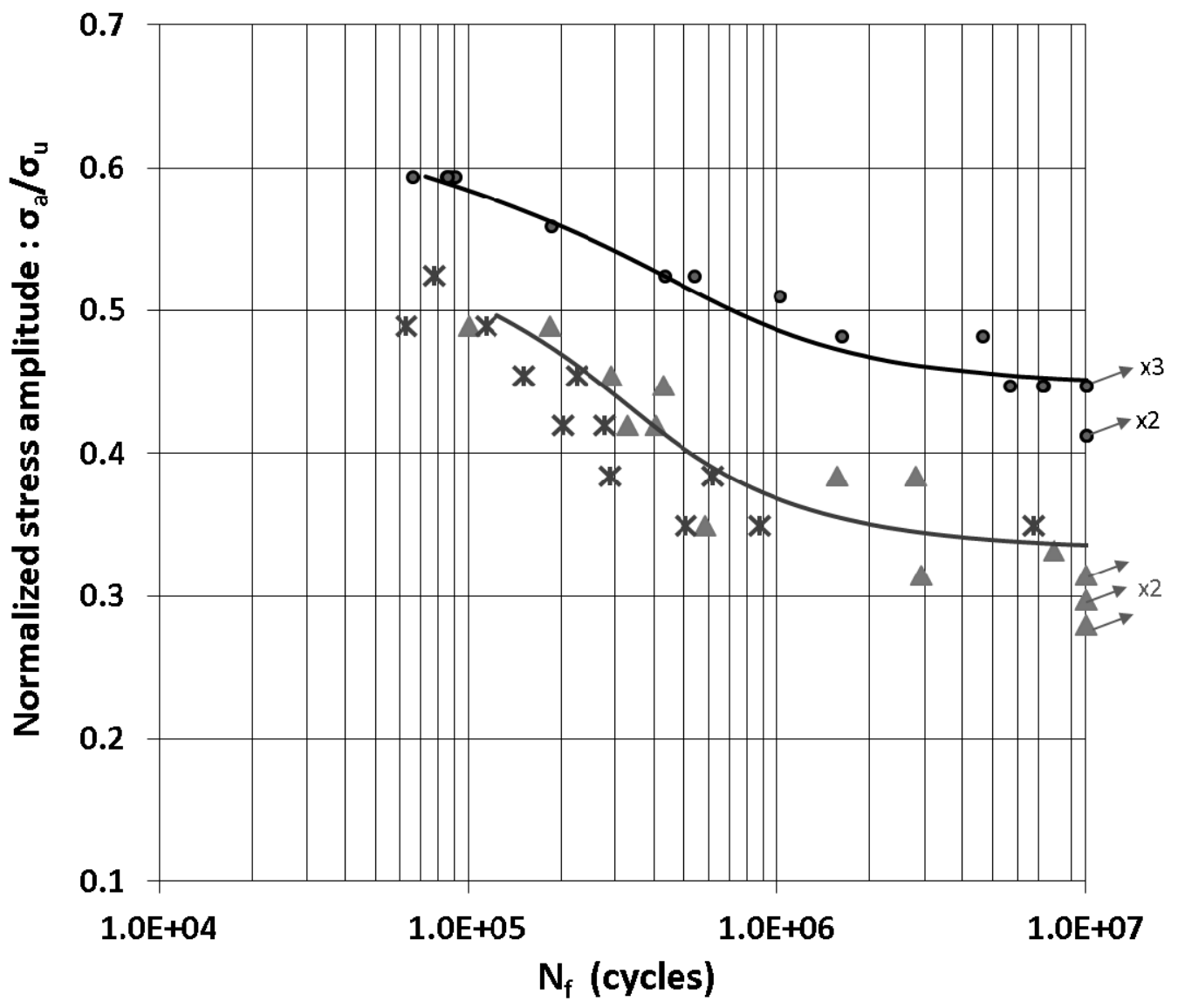

- in air at $120 \mathrm{~Hz}$

$\Delta$ in $0.1 \mathrm{M} \mathrm{NaCL}+0.044 \mathrm{M} \mathrm{Na} 2 \mathrm{SO} 4$ at $120 \mathrm{~Hz}$

* in $0.1 \mathrm{M} \mathrm{NaCl}+0.044 \mathrm{M} \mathrm{Na} 2 \mathrm{SO} 4$ at $10 \mathrm{~Hz}$

Figure 15: Fatigue test results and S-N curves of corrosion fatigue tests for two different loading frequencies $(120 \mathrm{~Hz}$ and $10 \mathrm{~Hz})$ at $\mathrm{R}=-1$ 
(a)

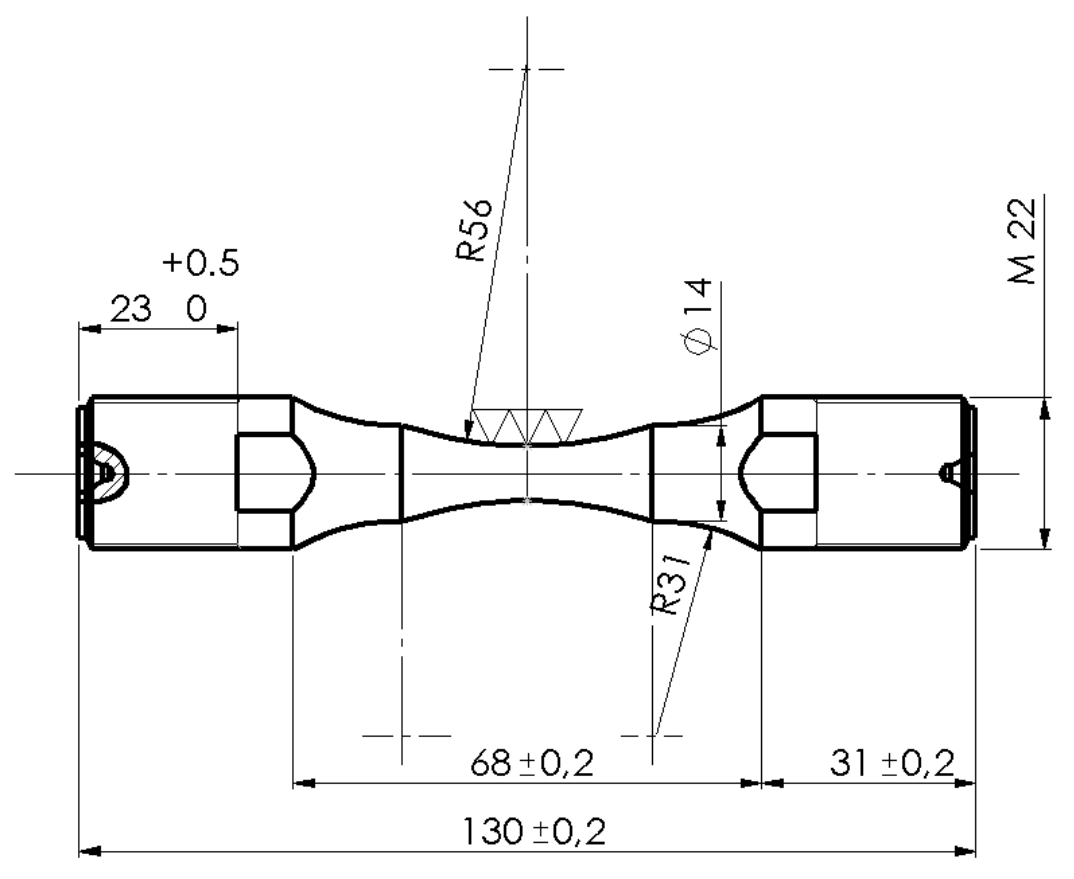

- $W \mathrm{Ra}<=0,1 \mu \mathrm{m}$

Rtmax $<=2 \mu \mathrm{m}$

- $\mathrm{Kt}=1.04$

(b)

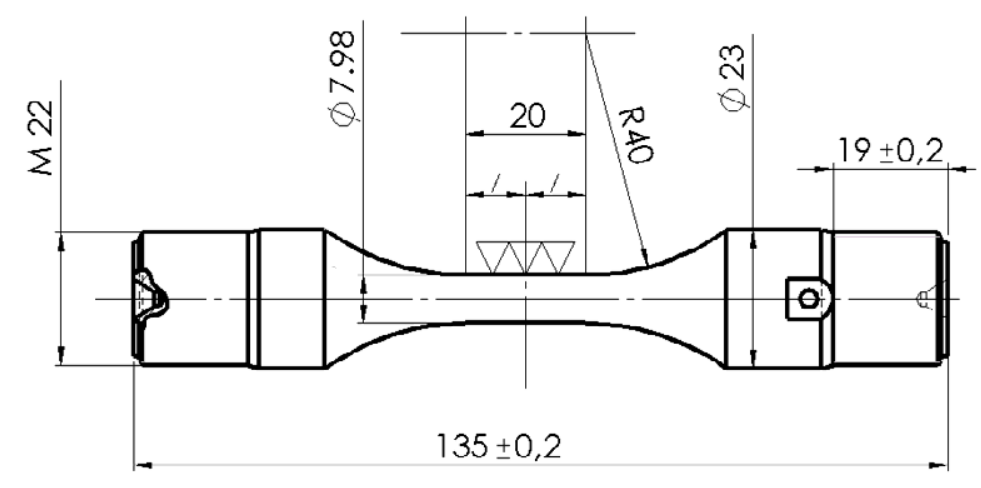

- $\mathrm{W} R \mathrm{Ra}<=0,1 \mu \mathrm{m}$

- $\mathrm{Kt}: 1.04$

Fig. 2 


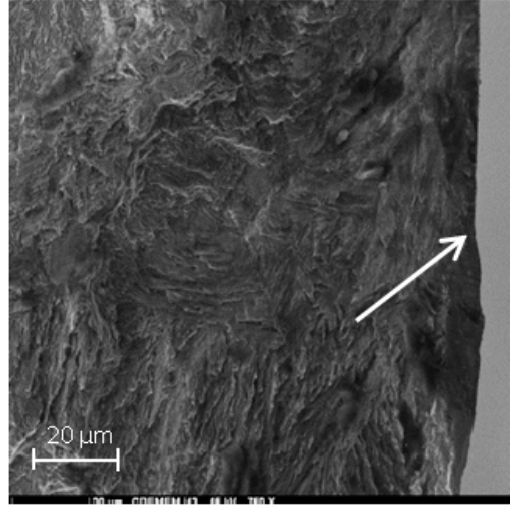

(0) $\sigma_{d} / \sigma_{u}=0.52 ; R=-1 ; \ln$ alr; $N_{4}=4.3 \times 10^{5}$ cydes

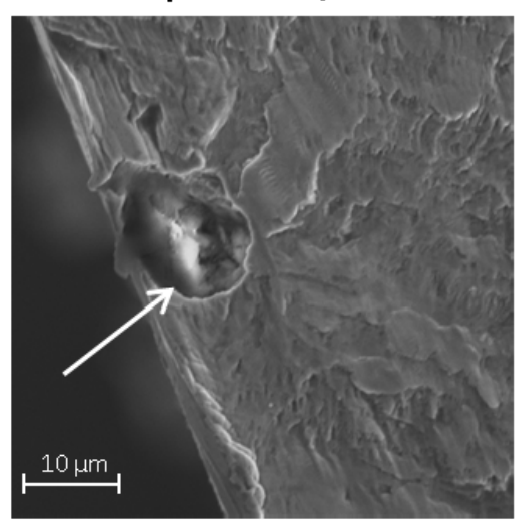

(e) $\sigma_{d} / \sigma_{u}=0.45 ; R=-1 ; \ln (0.1 \mathrm{M} \mathrm{Nad}+$ $\left.0.044 \mathrm{MNe}_{2} \mathrm{SO}_{4}\right) ; \mathrm{N}_{4}-4.3 \times 10^{5}$ cydes

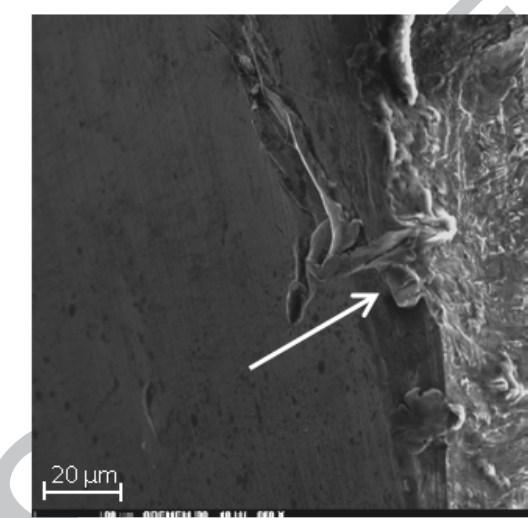

(0) $\sigma_{d} / \sigma_{u}=0.28 ; R=0.1 ; \ln (0.1 \mathrm{M}$ $\left.\mathrm{Ne}_{2} \mathrm{SO}_{4}\right) ; \mathrm{N}_{4}-4.5 \times 10^{5}$ cydes

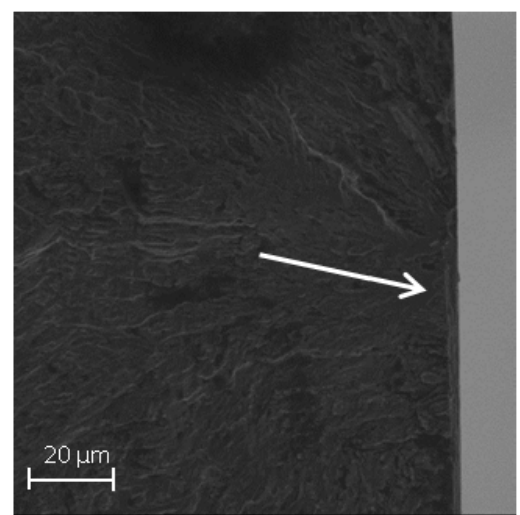

(b) $\sigma_{d} / \sigma_{u}=0.42 ; R=0.1 ; \ln$ alr; $\mathrm{N}_{4}=8.6 \times 10^{4}$ cycles

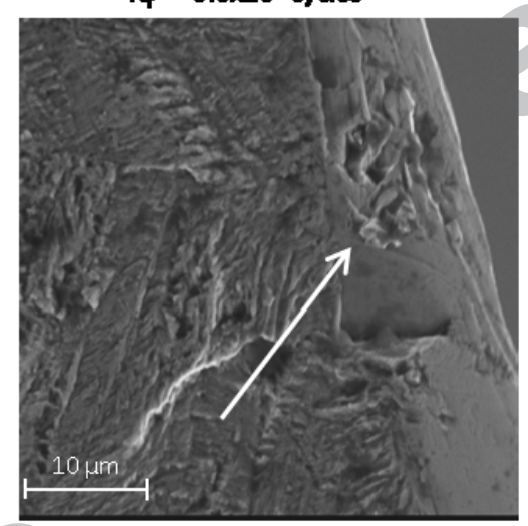

(d) $\sigma_{d} / \sigma_{u}=0.23 ; R=0.1 ; \ln (0.1 \mathrm{M} \mathrm{NaCl}$ $+0.044 \mathrm{MNe}_{2} \mathrm{SO}_{4}$ ); $4-9.2 \times 10^{5}$ cycles

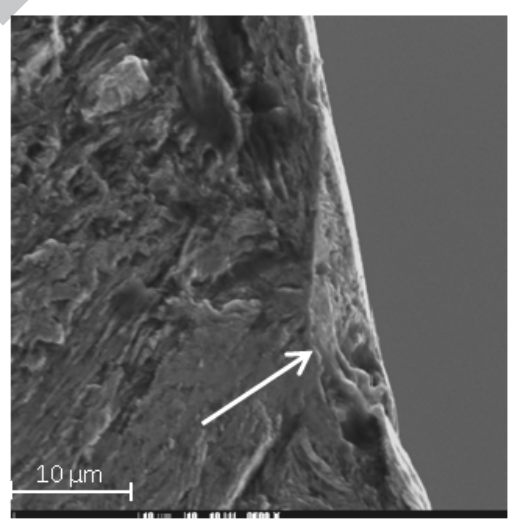

(f) $\sigma_{d} / \sigma_{u}-0.28 ; R=0.1 ;$ In dlstllled water; $\mathrm{N}_{4}-7.6 \times 10^{5}$ cycles

Fig. 5 


\section{ACCEPTED MANUSCRIPT}

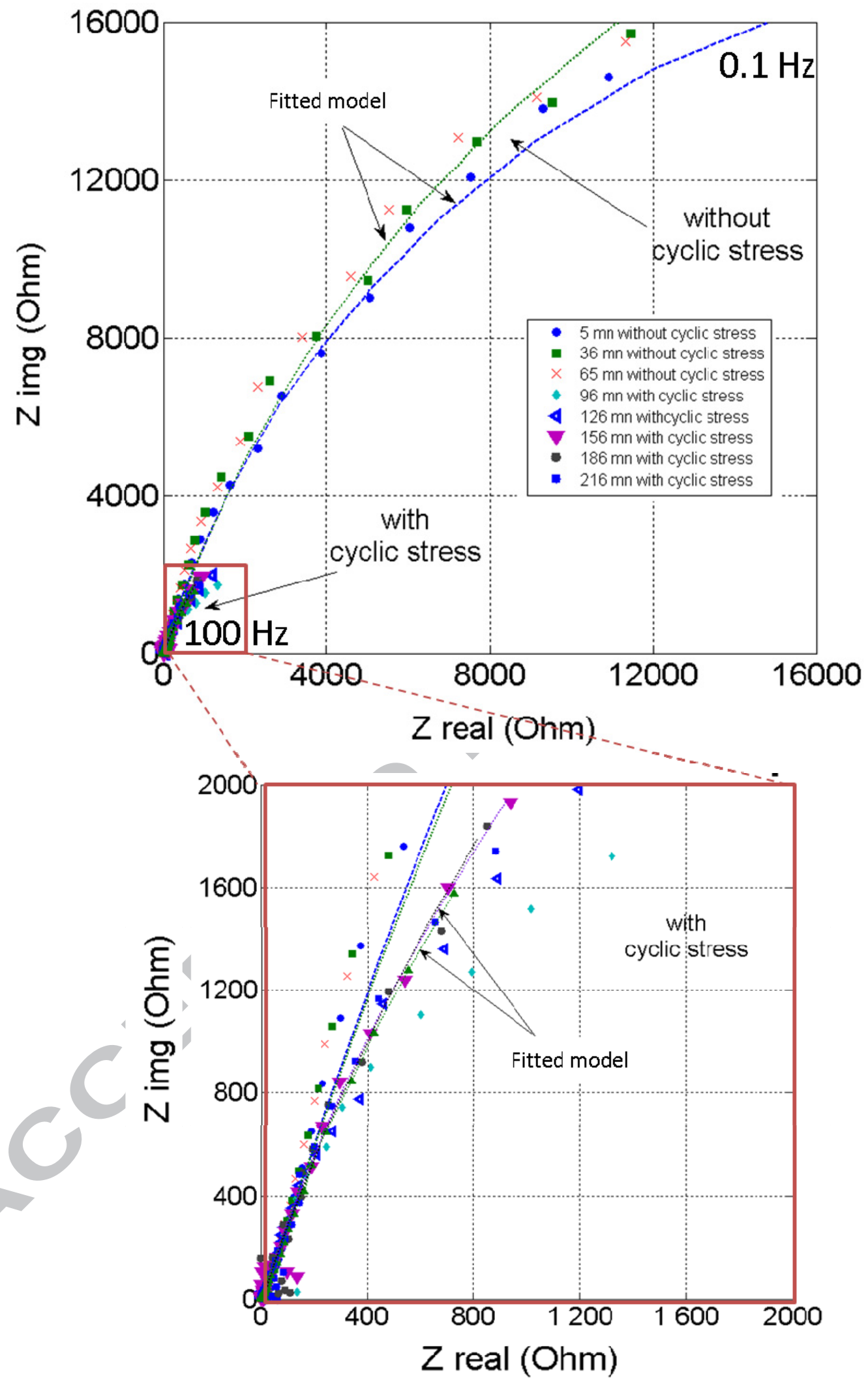

Fig. 10 
(a)

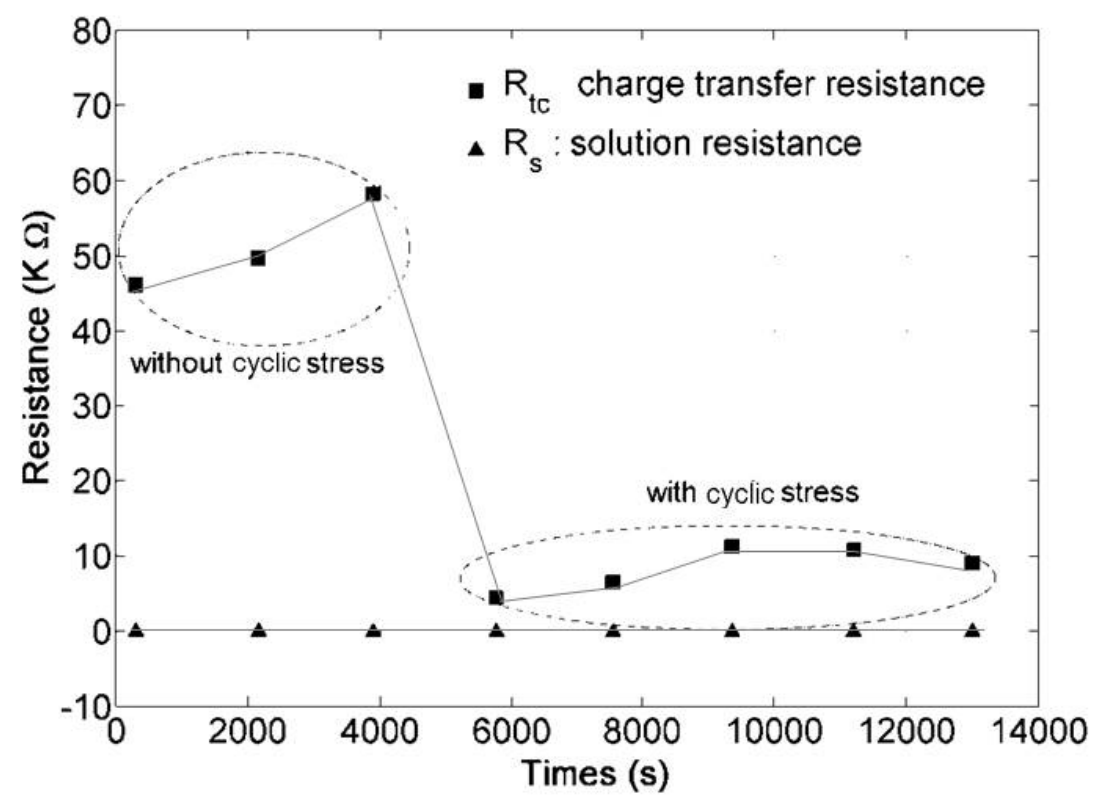

(b)

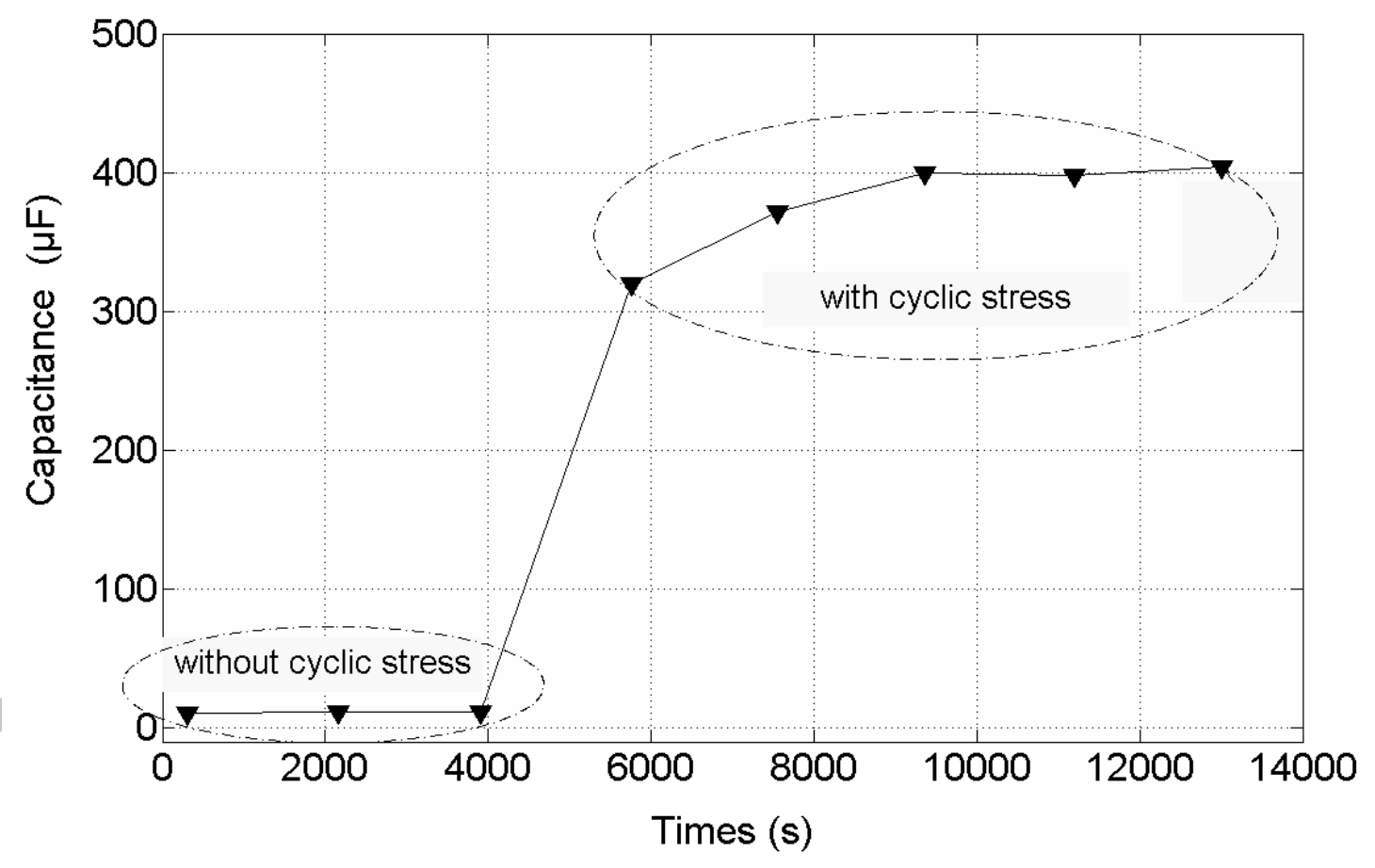

Fig. 11 


\section{Mohamed EL MAY, Thierry PALIN-LUC, Nicolas SAINTIER, Olivier DEVOS}

To the reviewers

Talence, the 13st of September 2012

Dear Reviewers,

We haven't changed the research highlights of this paper in the revised version. The research highlights are:

- Corrosion fatigue tests are carried out in high cycle regime (1E7 cycles) at 10 and $120 \mathrm{~Hz}$;

- In situ electrochemical measurements were carried out during corrosion fatigue tests;

- Behaviour of the passive film was studied during corrosion fatigue tests in $\mathrm{NaCl}$ aqueous solution;

- A scenario of corrosion fatigue crack initiation is proposed based on physical evidences.

Best regards,

Mohamed EL MAY, Thierry PALIN-LUC, Nicolas SAINTIER, Olivier DEVOS 